\title{
In situ adsorption of mercury, methylmercury and other elements by iron oxyhydroxides and organic matter in lake sediments
}

\author{
Stéphane Feyte ${ }^{a}$, André Tessier $^{a,}{ }^{*}$, Charles Gobeil $^{\mathrm{a}}$ and Daniel Cossa ${ }^{\mathrm{b}}$ \\ a INRS-ETE, Université du Québec, 490 de la Couronne, Québec, Qc, Canada G1K 9A9 \\ ${ }^{\mathrm{b}}$ Ifremer, Centre de Méditerranée, BP330, 83507 La Seyne sur Mer Cedex, France \\ *: Corresponding author : A. Tessier, Tel.: +1 418654 2632; fax: +1 418654 2600, email address : \\ atessier@ete.inrs.ca
}

\begin{abstract}
:
Samples of authigenic material, sediment overlying water and oxic surface sediment $(0-0.5-\mathrm{cm}$ depth) from a perennially oxygenated lacustrine basin were analysed to investigate which solid phases are important for binding a suite of trace elements ( $\mathrm{Ag}, \mathrm{As}, \mathrm{Ca}, \mathrm{Cd}, \mathrm{Cu}, \mathrm{Hg}, \mathrm{In}$, methylmercury (MeHg), $\mathrm{Mg}, \mathrm{Mo}, \mathrm{Pb}, \mathrm{Sb}$ and $\mathrm{Zn}$ ). The authigenic material, which was collected with inert Teflon sheets deployed for several years across the sediment-water interface, contained mainly poorly crystallized $\mathrm{Fe}$ oxyhydroxides and natural organic matter, presumably humic substances derived from the watershed. Manganese oxyhydroxides were not present in the collected authigenic material due to the slightly acidic condition $(\mathrm{pH}=5.6)$ of the lake that prevents the formation and recycling of these compounds. Conditional equilibrium constants for the adsorption of cationic $\left(K_{\mathrm{Fe}-\mathrm{M}}\right)$ and anionic $\left(K_{\mathrm{Fe}-\mathrm{A}}\right)$ trace elements onto the authigenic Fe oxyhydroxides were estimated from their concentrations in the authigenic material and in bottom water samples. These field-derived values of $K_{\mathrm{Fe}-\mathrm{M}}$ and $K_{\mathrm{Fe}-\mathrm{A}}$ were compared with those predicted by the surface complexation model, using laboratory-derived intrinsic adsorption constants and the water composition at the study site. Equilibrium constants $\left(K_{\mathrm{POM}-\mathrm{M}}\right)$ were also calculated for the adsorption of the cationic trace elements onto the humic substances contained in the diagenetic material. The field-derived values of $K_{\mathrm{POM}-\mathrm{M}}$ were compared to those predicted by the speciation code WHAM 6 for the complexation of the trace elements by dissolved humic substances in the lake. Combining the results of the present study with those on the distributions of trace elements in the porewater and solid-phase sediments reported in previous studies at the same site, it was determined whether the trace elements bind preferentially to Fe oxyhydroxides or natural organic matter in oxic sediments. The main inferences are that the anionic trace elements $\mathrm{As}$, Mo and Sb, as well as the cationic metal $\mathrm{Pb}$ are preferentially bound to the authigenic Fe oxyhydroxides whereas the other trace elements, and especially $\mathrm{Hg}$ and $\mathrm{MeHg}$, are preferentially bound to the humic substances.
\end{abstract}




\section{Introduction}

Bottom sediments comprise detrital organic and inorganic compounds as well as products derived from diagenetic reactions (e.g., Fe and Mn oxides). The diverse components that constitute the complex sediment matrix do not usually exist as separate particles but rather as aggregates (Jenne, 1968; Davis and Kent, 1990). Knowledge of how trace elements partition among these sediment components is desirable to better understand their geochemical mobility and cycling, and to estimate their bioavailability. However, the direct measurement of trace element association with a given sediment component is seldom feasible, due to the low concentrations of the trace elements involved and to the inherent complexity of sediment composition. The fact that some of the most important sedimentary phases for binding the trace elements may themselves be present at low concentrations, i.e., diluted in the sediment matrix, also adds further complication.

In this context, there is reliance on several approaches that can provide indirect information about the association of trace elements to sediment components. Methods involving extraction of sediments with reagents of various strengths have been used to partition trace elements into broad geochemical classes (Tessier et al., 1979; Chao and Zhou, 1983; Bacon and Davidson, 2008; Linge, 2008). Although such procedures can yield useful information about trace element binding to sediment components, it is generally recognized that the results obtained depend on factors such as the choice of reagents and the duration of extraction (Bacon and Davidson, 2008). Other limitations are that the reagents are generally not completely selective towards targeted sedimentary trace element forms and that the extracted trace elements can readsorb onto other sediment components (Bacon and Davidson, 2008). Search for statistical relationships between concentrations of trace elements and those of the sediment components that can bind them is another approach that has been often used to obtain information about trace element binding (Luoma and Bryan, 1981; Sigg et al., 1987; Hammerschmidt and Fitzgerald, 2006). However, statistically significant relationships are not sufficient by themselves to demonstrate the association of a trace element with a sediment component. Following the advent of synchrotrons, a most promising approach to obtain the sought information, is the application to the sediments of X-ray spectroscopy techniques such as Extended X-ray Absorption Fine Structure (EXAFS) and X-ray Absorption Near Edge Structure (XANES); these techniques can yield information such as the oxidation state of the elements, the number and type of their neighbours, the coordination state, and the bond distance between atoms (Murata, 1991; Parsons et al., 2002; Zhao et al., 2006; Singer et al., 2009). Main limitations of these molecular techniques are, however, their lack of sensitivity for most trace elements in environmental samples, the limited access to instruments and, in some cases, the absence of appropriate reference material (Murata, 1991; Zhao et al., 2006).

This study investigates trace element ( $\mathrm{Ag}, \mathrm{As}, \mathrm{Cd}, \mathrm{Cu}, \mathrm{Hg}$, In, methylmercury (MeHg), Mo, Pb, Sb and $\mathrm{Zn}$ ) binding in an oxic lacustrine sediment by combining in situ techniques and thermodynamic modeling. The oxic layer of sediments is important in the overall cycling of trace elements because it is the locus of several diagenetic reactions that can profoundly influence their behaviour. The importance of adsorption of trace elements onto diagenetic Fe and Mn oxyhydroxides and organic matter has been inferred in several studies (e.g., Davis and Kent, 1990) and its theoretical treatment is emphasized here. The trace elements studied are all known regional or global atmospheric pollutants (e.g. Pacyna and Pacyna, 2001; Krachler and Shotyk, 2004; Laforte et al., 2005; Ranville and Flegal, 2005) and Mo is also a potential tracer of past fluctuations in organic C flux at the sediment-water interface and/or in bottom water $\mathrm{O}_{2}$ concentration (e.g. Crusius et al., 1996; Adelson et al., 2001). Among these trace elements, special attention is paid to $\mathrm{Hg}$ and $\mathrm{MeHg}$ for which binding information is urgently required to better understand the $\mathrm{Hg}$ cycle at the sediment-water interface. The study was carried out in the perennially oxygenated lacustrine basin of Lake Tantaré $\left(47^{\circ} 04^{\prime} \mathrm{N}, 71^{\circ} 32^{\prime} \mathrm{W}\right)$, an acidic and oligotrophic Canadian Shield lake whose watershed is uninhabited. Authigenic material (Belzile et al., 1989), surficial sediment and bottom 
water samples were collected at the deepest site $(15 \mathrm{~m})$ of the westernmost basin of this lake, and an extensive dataset comprising the authors' own analyses, as well as results obtained in previous studies carried out by the authors' group at the same site (Alfaro-De la Torre and Tessier, 2002; Gallon et al., 2004; Quirion, 2004; Laforte, 2005; Chappaz, 2008; Couture et al., 2008; Bernatchez, 2009), were used to clarify the mode of association of trace elements in oxic lake sediments.

\section{Material and methods}

Clean techniques were used to avoid sample contamination during field work and subsequent chemical analysis in the laboratory. Hereafter, $[X]$ and $\{X\}$ refer to the concentrations of species $X$ in the aqueous and solid phases, respectively, dissolved inorganic $\mathrm{Hg}$ concentration $\left([\mathrm{Hg}]_{\mathrm{I}}\right.$ ) is assumed to be the difference between total dissolved $\mathrm{Hg}\left([\mathrm{Hg}]_{\mathrm{T}}\right)$ and dissolved $\mathrm{MeHg}([\mathrm{MeHg}])$, and, similarly, sediment inorganic $\mathrm{Hg}\left(\{\mathrm{Hg}\}_{1}\right)$ is assumed to be the difference between total sediment $\mathrm{Hg}\left(\{\mathrm{Hg}\}_{\mathrm{T}}\right)$ and sediment $\mathrm{MeHg}(\{\mathrm{MeHg}\})$.

\subsection{Sampling}

Twelve acrylic in situ dialysis samplers (peepers; 1-cm vertical resolution; two columns of 4-mL cells) similar to those described by Carignan et al. (1985) were used to sample the water within the $5-\mathrm{cm}$ thick layer above the sediment-water interface for the determination of $\mathrm{pH},[\mathrm{Hg}]_{\mathrm{T}},[\mathrm{MeHg}]$, $[\mathrm{Cu}],[\mathrm{Zn}],[\mathrm{Al}],[\mathrm{Fe}]$ and $[\mathrm{Mn}]$ as well as for measuring the concentrations of major cations and anions and organic $C$. The acid-washed peeper cells were filled with ultrapure water $(>18 \mathrm{M} \Omega \mathrm{cm})$ and covered with a pre-cleaned $0.2 \mu \mathrm{m}$ nominal pore size polysulfone membrane (HT-200, Gelman). The peepers were deployed by divers in September 2006 and retrieved 3 weeks later.

Water contained in the cells of 3 peepers positioned at a given height above the sediment-water interface was obtained by piercing the polysulfone membrane with an acid-washed plastic tip fixed on a 5-mL Gilson pipette. The pooled sample (total volume of $24 \mathrm{~mL}$ ) was put in cleaned Teflon (PFA) bottles and shaken. A 1-mL aliquot was transferred to a preacidified (10 $\mu \mathrm{L}$ of $2 \mathrm{~N}$ SeaStar $\mathrm{HNO}_{3}$ ) vial for the determination, after dilution, of [Al], [Ca], [Cu], [Fe], [K], [Mg], [Mn], [Na] and [Zn]. The remaining 23-mL sample was acidified with $115 \mu \mathrm{L}$ of suprapur (SeaStar) $0.5 \%(\mathrm{v} / \mathrm{v}) \mathrm{HCl}$ and kept for the measurements of $[\mathrm{Hg}]_{\mathrm{T}}$ and $[\mathrm{MeHg}]$; the Teflon bottles were then sealed in double plastic bags. Nine of the peepers were sampled in this manner in order to get triplicate measurements of each metal for each of the 5 depth intervals above the sediment-water interface. The 3 peepers left were used for triplicate measurements of $\mathrm{pH}$, dissolved organic $\mathrm{C}$ and major anions according to protocols described by Alfaro-De la Torre and Tessier (2002). Samples of water overlying the sediment had been obtained in previous studies at the same sampling site using similar methodology, and $\mathrm{Ag}, \mathrm{As}, \mathrm{Cd}, \mathrm{In}, \mathrm{Mo}, \mathrm{Pb}$ and $\mathrm{Sb}$ were measured in these samples (AlfaroDe la Torre and Tessier, 2002; Gallon et al., 2004; Quirion, 2004; Laforte, 2005; Chappaz, 2008; Couture et al., 2008; Bernatchez, 2009).

Sheets of skived Teflon $(7 \mathrm{~cm} \times 15 \mathrm{~cm})$ that had been inserted by divers across the sediment-water interface at the sampling site in October 1993 were retrieved in August 2006, rinsed with lake water to remove living animals and sediment particles and stored in polyethylene containers. Iron recycling is commonly observed in oxygenated aquatic environments due to the reduction of reactive $\mathrm{Fe}(\mathrm{III})$ in the lower sediment strata, upward diffusion of porewater $\mathrm{Fe}(\mathrm{II})$, and its oxidation and precipitation as $\mathrm{Fe}(\mathrm{III})$ oxyhydroxides in the top sediment layers. The observation at the sampling site of a large excess in $\{\mathrm{Fe}\}$ just below the sediment surface and of a sharp [Fe] gradient close to the sediment-water interface indicate intense Fe redox recycling (Fig. 1). In contrast, the absence of excess $\{\mathrm{Mn}\}$ and of [Mn] gradients indicates that $\mathrm{Mn}$ does not recycle in the sediments of this low $\mathrm{pH}$ lake. The authigenic Fe oxyhydroxides that are normally deposited to sediment particles close to the sediment surface can also be collected by other material inserted in 
sediments, such as Teflon sheets (Belzile et al., 1989). The diagenetic Fe-rich material collected during the 13-a deployment of the Teflon sheets appeared as a $\mathrm{mm}$ thick crust.

A sediment core was collected in June 2006 by a diver using a $9.5 \mathrm{~cm}$ internal diameter butyrate tube. The core was extruded and sectioned within $2 \mathrm{~h}$, with only the top $0.5 \mathrm{~cm}$ retained for this study. At the sampling site, $\mathrm{O}_{2}$ penetrates down to about $0.3 \mathrm{~cm}$ depth below the sediment-water interface (Couture et al., 2010b) and sulfide concentration is below detection limit in the top $2-3 \mathrm{~cm}$ of the sediments (Alfaro-De La Torre and Tessier; Chappaz et al., 2008; Gallon et al., 2004). Thus, according to the generally accepted definition, the upper part (about $3 \mathrm{~mm}$ ) of the top 0.5-cm sediment layer was oxic and the lower part (about $2 \mathrm{~mm}$ ) was suboxic. However, to simplify, this sediment sample is referred to as being oxic. Authigenic $\mathrm{Fe}$ in this sediment sample should be essentially $\mathrm{Fe}(\mathrm{III})$ oxyhydroxides since porewater over the $0-0.5 \mathrm{~cm}$ sediment depth interval is undersaturated with respect to $\mathrm{Fe}(\mathrm{OH})_{2(\mathrm{~s})}, \mathrm{FeCO}_{3(\mathrm{~s})}$ and $\mathrm{FeS}_{\mathrm{m}(\mathrm{s})}$ (mackinawite), whose saturation indices $(S I)$, defined as $S I=\log I A P / K_{s}$, where $I A P$ stands for ion activity product, were lower than $5.0,-2.0$ and -3.5 , respectively. This sediment sample was stored in a polyethylene container and freeze-dried upon return to the laboratory.

\subsection{Analyses}

The method used to measure $[\mathrm{Hg}]_{\mathrm{T}}$ (Cossa et al., 2003) was modified from that of Bloom and Fitzgerald (1988). It is similar to EPA standard method No1631. Briefly, $[\mathrm{Hg}]_{\mathrm{T}}$ was determined, using external calibration, by cold vapor atomic fluorescence spectrometry (CVAFS; Tekran model 2500) after successive addition of $\mathrm{BrCl}$ to release $\mathrm{Hg}(\mathrm{II})$ from its ligands, and $\mathrm{SnCl}_{2}$ to reduce it to elemental $\mathrm{Hg}(\mathrm{Hg}(0))$. Detection limit $(\mathrm{DL})$, defined as 3.3 times the standard deviation of 6 blank analyses (this definition is valid for all the analyses described below), was $0.4 \mathrm{pM}$ for a $10-\mathrm{mL}$ water sample. Precision, determined from 6 replicate measurements of $20 \mathrm{pM} \mathrm{Hg}$ samples, was better than $5 \%$, but was reduced to $15 \%$ when sample $\mathrm{Hg}$ concentration decreased to $1 \mathrm{pM}$. Analytical accuracy was checked every day with the certified reference material ORMS-3 from the National Research Council of Canada (NRC).

Dissolved $\mathrm{MeHg}$ was converted to volatile $\mathrm{MeHg}$ hydride, separated by purge and cryo-trapping gas chromatography, and detected as elemental $\mathrm{Hg}$ vapor by atomic fluorescence spectrometry (AFS Tekran Model 2500). The hydride generation technique proposed by Stoichev et al. (2004) was optimized as described in detail by Cossa et al. (2009). The DL was $0.2 \mathrm{pM}$ for a $10-\mathrm{mL}$ sample. Analytical reproducibility, determined from 6 replicates, was better than 15\% near the DL and 6\% at a concentration of $0.5 \mathrm{pM}$. Accuracy was checked using the certified reference material (CRM) ERM-AE670 from the Institute for Reference Materials and Measurements (IRMM, European Commission).

Total sedimentary $\mathrm{Hg}$ concentration $\left(\{\mathrm{Hg}\}_{T}\right)$ was determined on freeze-dried sediment aliquots using an automatic mercury analyzer (Milestone DMA-80). This method, also known as the EPA standard method No 7473, includes a pyrolysis step that releases $\mathrm{Hg}$ from the sample. Mercury is then concentrated by Au amalgamation and detected by atomic absorption spectrometry (Cossa et al.,

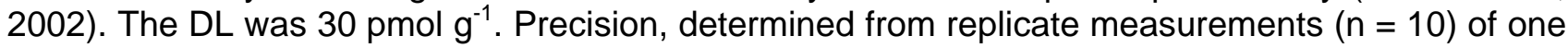
of the sediment samples, was better than $5 \%$. Accuracy was determined with the CRM MESS-3 from NRC and was lower than 5\%.

Solid phase $\mathrm{MeHg}$ concentrations $(\{\mathrm{MeHg}\})$ were determined using a method described by Cossa et al. (2002) and adapted from Leermakers et al. (2001). Methylmercury was solubilized in $4 \mathrm{M}$ $\mathrm{HNO}_{3}$ from a freeze-dried sediment aliquot, then extracted by $\mathrm{CH}_{2} \mathrm{Cl}_{2}$ and transferred into $40 \mathrm{~mL}$ of demineralized water (Milli-Q) by evaporation of the organic solvent. Methylmercury in the water phase was then ethylated and purged on a Tenax packed column. Ethylmethylmercury was isolated from other volatile compounds by gas chromatography and quantified by CVAFS. The DL was 0.1 pmol $\mathrm{g}^{-1}$. Analytical precision, determined from replicate analyses $(n=6)$, was less than $15 \%$. 
Recoveries of MeHg were $91 \pm 8 \%(n=6)$ in the CRM 405 material from the International Atomic Energy Agency (IAEA).

As in the authors' previous studies (e.g., Gallon et al., 2004; Chappaz et al., 2008), the sediment samples collected in Lake Tantaré were completely mineralized with a mixture of $\mathrm{HNO}_{3}, \mathrm{HClO}_{4}$ and $\mathrm{HF}$; the acids were evaporated to near dryness and residues were redissolved in a $0.2 \mathrm{~N} \mathrm{HNO}_{3}$ solution. Methodology to measure $\mathrm{pH}$ and the concentrations of $\mathrm{Al}, \mathrm{Ca}, \mathrm{Fe}, \mathrm{K}, \mathrm{Mg}, \mathrm{Mn}, \mathrm{Na}, \mathrm{Cl}, \mathrm{SO}_{4}$, and organic and inorganic $\mathrm{C}$ in the water samples and those of $\mathrm{Fe}, \mathrm{Mn}$, total $\mathrm{C}$ and $\mathrm{N}$ in the sediments, are described by Laforte et al. (2005). The concentrations of dissolved and sedimentary $\mathrm{Cu}, \mathrm{Zn}$ and Mo (Chappaz et al., 2008), In (Laforte, 2005), Sb (Bernatchez, 2009) and Ag (Quirion, 2004) were determined with a quadrupole ICP-MS (Thermo Instrument X7) whereas those of Cd (Alfaro-De la Torre and Tessier, 2002) and $\mathrm{Pb}$ (Gallon et al., 2004) were measured by graphite furnace atomic absorption spectrometry (Perkin-Elmer SIMAA 6000; Zeeman correction) and those of As, by hydride generation-atomic absorption spectrometry (HG-AAS; Couture et al., 2008).

Areas of the Teflon sheets containing the Fe-rich authigenic deposits were cut and dissolved in $50 \% \mathrm{HCl}$ for $48 \mathrm{~h}$ at room temperature. The resulting solutions were filtered through $0.4-\mu \mathrm{m}$ porosity Teflon filters and diluted 10 times. In these solutions, Al, $\mathrm{Ca}, \mathrm{Fe}, \mathrm{K}, \mathrm{Mg}$ and $\mathrm{Na}$ were measured by inductively coupled plasma optical emission spectrometry (ICP-OES; VISTA AX CCD), Ag, Cd, Cu, In, $\mathrm{Mo}, \mathrm{Pb}, \mathrm{Sb}$ and $\mathrm{Zn}$, by inductively coupled plasma mass spectrometry (ICP-MS; Thermo Instrument X7), As by HG-AAS, and $\mathrm{C}$ and $\mathrm{N}$ with a Shimadzu $\mathrm{C} \mathrm{N}$ analyzer; $\mathrm{Hg}$ and $\mathrm{MeHg}$ were measured as described above for dissolved $\mathrm{Hg}$ and $\mathrm{MeHg}$.

\section{Results and discussion}

\subsection{Thermodynamic predictions of chemical speciation and saturation index}

Speciation of dissolved trace elements in the oxic water overlying the sediment was calculated with the computer program "Windermere Humic Aqueous Model" (WHAM 6; Tipping, 2002) using measured $\mathrm{pH}$ and total concentrations of dissolved $\mathrm{Ag}, \mathrm{Al}, \mathrm{As}, \mathrm{Ca}, \mathrm{Cd}, \mathrm{Cu}, \mathrm{Fe}$, In, inorganic $\mathrm{Hg}$, $\mathrm{MeHg}, \mathrm{Mg}, \mathrm{Mn}, \mathrm{Mo}, \mathrm{Na}, \mathrm{K}, \mathrm{Pb}, \mathrm{Sb}, \mathrm{Zn}$, as well as those of $\mathrm{SO}_{4}, \mathrm{Cl}, \mathrm{CO}_{3}$, and humic (HA) and fulvic (FA) acids as inputs. It was assumed that all As, Sb and Mo exist in the oxic water of Lake Tantaré as $\mathrm{As}(\mathrm{V})$ (Couture et al., 2008), Sb(V) (Bernatchez, 2009) and Mo(VI) (Chappaz et al., 2008) species. The concentrations of HA and FA were estimated from measurements of dissolved organic carbon $\left(\mathrm{C}_{\text {org }}\right)$, assuming that dissolved organic matter contains $50 \% \mathrm{C}$ (Buffle, 1988) and that all $\mathrm{C}_{\text {org }}$ is a part of humic substances (HS) with a ratio of [FA]:[HA] of 9:1 (Malcolm, 1985).

The WHAM 6.0 database was updated with the thermodynamic data given in Table 1 for Ag, As, $\mathrm{Hg}, \mathrm{In}, \mathrm{MeHg}, \mathrm{Mo}$ and $\mathrm{Sb}$; note that $\mathrm{Ag}^{+}, \mathrm{In}^{3+}, \mathrm{MeHg}^{+}, \mathrm{MoO}_{4}{ }^{2-}$ and $\mathrm{Sb}(\mathrm{OH})_{6}{ }^{-}$were new components added to the speciation code WHAM 6 . The formation constants chosen for the complexation of $\mathrm{Hg}$ and $\mathrm{MeHg}$ with HA and FA were recently provided by Tipping (2007) who critically reviewed laboratory studies describing $\mathrm{Hg}$ and $\mathrm{MeHg}$ complexation with HA and FA; the WHAM 6 speciation code was also modified to include the values of the empirical parameter used to take into account $\mathrm{HA}$ and FA binding site heterogeneity $\left(\Delta L K_{2}\right)$ suggested by Tipping (2007), i.e., 5.1 and 3.6 for $\mathrm{Hg}$ and $\mathrm{MeHg}$, respectively. It should be noted that the formation constants of $\mathrm{Hg}$ complexes with $\mathrm{HA}$ and FA are reasonably reliable because the experimental data available in the literature for extracting these constants cover a wide range of conditions ( $\mathrm{pH}$ and levels of metal binding); however, the formation constants for the $\mathrm{MeHg}$ complexes remain uncertain due to the relatively limited experimental data basis available (Tipping, 2007). Formation constants of In complexes with HA and FA were estimated for WHAM 6, as suggested by Carbonaro and Di Toro (2007) for a previous version of the speciation code WHAM. A $\Delta L K_{2}$ value of 2.2 was estimated for In, as in 
equation 1 (Tipping, 1998), assuming that $\Delta L K_{2}$ is related to the equilibrium constant for In complexation with $\mathrm{NH}_{3}\left(K_{N H 3}\right.$; value taken from Mulla et al., 1985):

$\Delta L K_{2}=0.55 \log K_{N_{3}}$

The formation constants for the complexation of $\mathrm{Cu}, \mathrm{Pb}$ and $\mathrm{Zn}$ with inorganic ligands and humic substances (HS) were those given in the WHAM 6 database. There is no formation constant for Ag, $\mathrm{As}, \mathrm{Sb}$ and Mo complexes with HA and FA.

Table 2 shows the free-ion activities, major species and saturation index (SI), as calculated by WHAM 6 for all elements. According to these calculations, almost $100 \%$ of $[\mathrm{Hg}]_{1}$ and about $12 \%$ of $[\mathrm{MeHg}]$ were associated with HS in the water overlying Lake Tantaré sediment. Association of the other elements with HS were predicted to be around $100 \%$ for $\mathrm{Cu}, 75 \%$ for $\mathrm{Pb}$ and $\mathrm{In}, 20-30 \%$ for $\mathrm{Cd}$ and $\mathrm{Zn}$ and $10-20 \%$ for $\mathrm{Ca}$ and $\mathrm{Mg}$ (Table 2). The negative SI values for all elements indicate that the bottom water of Lake Tantaré was largely undersaturated with respect to their least soluble solids. Thus, the trace elements found in association with the authigenic Fe-rich material (Table 3) were presumably bound to it by adsorption.

\subsection{Possible binding phases for the trace elements in the Fe-rich authigenic material}

Fortin et al. (1993) reported that poorly crystallized lepidocrocite and ferrihydrite were the main Fe oxyhydroxides (Fe-ox) in the Fe-rich material collected on Teflon sheets in Lake Tantaré. The $\mathrm{C}_{\text {org }} / \mathrm{Fe}$ molar ratio found for this material $(2.6 \pm 0.3$; Table 3$)$ indicates that a large amount of organic matter is associated with the authigenic Fe oxyhydroxides. The $\mathrm{C}_{\text {org }} / \mathrm{N}$ molar ratio of this organic matter (15.3 \pm 3.4 ; Table 3$)$ is much higher than the $\mathrm{C}_{\text {org }} / \mathrm{N}$ Redfield ratio assigned to phytoplankton (6.63; Redfield, 1934), but close to that reported for humic substances (17.5; Buffle, 1988). It is also much larger than the value $\left(C_{\text {org }} / N=6.4\right)$ reported for particles collected in sediment traps deployed from April to October in the productive lake Windermere, UK (Hamilton-Taylor et al., 1984) and the $\mathrm{C}_{\text {org }} / \mathrm{N}$ values of 7.7 - 8.8 reported for the sediments of the eutrophic Gulf of Riga in the Baltic Sea (Danielsson et al., 1998). Following these observations, it is concluded that most of the organic matter in the diagenetic material collected on Teflon sheets is of terrestrial origin; such organic material is reputed to contain mainly humic substances (Buffle, 1988).

The close association of HS with metal oxyhydroxides is ubiquitous in soils and sediments; humic substances are presumed to coprecipitate with metal oxyhydroxides (Schwertmann et al., 2005) or to adsorb on their surface by a variety of mechanisms including ligand exchange, cation bridging, hydrogen bonding and van der Waals interactions (Sposito, 1984; McKnight et al., 1992; Gu et al., 1994; Schlautman and Morgan, 1994). Molar $C_{\text {org }} / F e$ ratios of similar magnitude to the one measured here have been reported for authigenic material collected by the same method in other lakes $\left(\mathrm{C}_{\text {org }} / \mathrm{Fe}=1.3-2.3\right.$; Tessier et al., 1996) and for Fe-rich particles formed in the water column of a seasonally anoxic lake ( $\mathrm{C}_{\mathrm{org}} / \mathrm{Fe}=1.2$ - 2.5; Tipping et al., 1981).

Langmuir isotherm parameters, namely the adsorption coefficient and the maximum density of adsorption, for the adsorption of humic substances on goethite at various $\mathrm{pHs}$ and on fresh and aged amorphous Fe oxyhydroxides at pH values around 7 have been provided by Tipping (1981). These data show that amorphous Fe oxyhydroxides adsorb 8.5 - 24 fold more HS than goethite at $\mathrm{pH}$ 7. Furthermore, from the Langmuir isotherm at pH 5.5 (i.e., close to the $\mathrm{pH} 5.6$ of Lake Tantaré) it can be predicted that $1 \mathrm{~g}$ of goethite in equilibrium with Lake Tantaré dissolved organic matter (5.1 $\mathrm{mg} \mathrm{HS} \mathrm{L}^{-1}$; Table 2) would adsorb $32 \mathrm{mg}$ of HS. If it is assumed that ferrihydrite adsorbs 8.5 24 fold more HS than goethite at $\mathrm{pH} 5.5$, one can then conclude that ferrihydrite would adsorb 272 $768 \mathrm{mg} \mathrm{HS} \mathrm{g}^{-1} \mathrm{Fe}-0 x$ (which would correspond to a $\mathrm{C}_{\text {org }} / \mathrm{Fe}$ molar ratio of 1.2 - 3.4. The $\mathrm{C}_{\text {org }} / \mathrm{Fe}$ molar ratio measured on the diagenetic material $(2.6 \pm 0.3$; Table 3$)$ falls within this range. Thus, based on the value of the $\mathrm{C}_{\text {org }} / \mathrm{N}$ ratio and on the concordance between the measured and predicted $\mathrm{C}_{\text {org }} / \mathrm{Fe}$ molar ratio, it is plausible to assume that most of the organic material associated with the diagenetic material is humic substances. Indeed, although biological material such as 
microorganisms remains and exocellular polymers can also be present in the diagenetic material (Fortin et al., 1993), these other types of organic matter likely occur in lesser amounts.

Calculations of the $\Sigma$ TE/Fe ratio (0.0075; Table 3), where $\sum T E$ is the sum of the molar concentrations of $\mathrm{Ag}, \mathrm{As}, \mathrm{Ca}, \mathrm{Cd}, \mathrm{Cu}, \mathrm{Hg}, \mathrm{In}, \mathrm{MeHg}, \mathrm{Mg}, \mathrm{Mo}, \mathrm{Sb}, \mathrm{Pb}$ and $\mathrm{Zn}$, indicates that the $-\mathrm{OH}$ sites on Fe oxyhydroxides would be in sufficient number to bind all of these elements. Alternatively, if it is assumed that FA and HA have a similar reactivity for Fe oxyhydroxides and that their concentrations of binding sites are $7.1 \times 10^{-3}$ mol per $\mathrm{g}$ of FA and $4.9 \times 10^{-3} \mathrm{~mol}$ per $\mathrm{g}$ of $\mathrm{HA}$, respectively (Tipping, 1994), it is estimated that the $\mathrm{C}_{\text {org }} / \mathrm{Fe}(2.6)$ measured in the authigenic material would correspond to 0.41 equivalent of adsorption sites per mole of Fe oxyhydroxide, which then is sufficient for humic substances to bind all trace metals found in the authigenic material.

Thus, the Fe-rich material deposited on the Teflon sheets contains sufficient Fe oxyhydroxides and organic matter to bind all trace elements, and, as a consequence, the following two scenarios have been examined.

\subsubsection{Scenario 1: Binding of trace elements to the Fe oxyhydroxides}

The framework provided by surface complexation theory can be used to examine if trace elements in the authigenic material collected on the Teflon sheets were bound to the hydroxyl groups of Fe oxyhydroxides. The following general equation, where charges on the solid species have been omitted for simplicity, can describe cation $(M)$ adsorption on diagenetic Fe oxyhydroxides (Tessier et al., 1996):

$$
\equiv \mathrm{Fe}-\mathrm{OH}_{x}+\mathrm{M}^{z+}=\quad \equiv \mathrm{Fe}-\mathrm{OM}+x \mathrm{H}^{+} \quad ;^{*} \mathrm{~K}_{\mathrm{Fe}-\mathrm{M}}
$$

In this equation ${ }^{*} K_{\mathrm{Fe}-\mathrm{M}}$ is an overall conditional equilibrium constant, $M^{2+}$ is the free-metal ion, $x$ is the apparent number of protons released per $M$ adsorbed and " $\equiv "$ refers to adsorption sites. If it is assumed that the proportion of sites occupied by $M$ is low, the concentration of free adsorption sites can be related to the concentration of Fe oxyhydroxides (i.e., $\{\equiv F e-O H\}=N_{\mathrm{Fe}}\{\mathrm{Fe}-\mathrm{Ox}\}$ where $N_{\mathrm{Fe}}$ is the number of moles of adsorption sites per mole of $\mathrm{Fe}$ oxyhydroxides and $\{\mathrm{Fe}-\mathrm{Ox}\}$ is the analytical concentration of Fe oxyhydroxides). With the additional assumption that the concentration of sites occupied by $M$ is equal to the concentration of $M$ associated with the Fe oxyhydroxides (i.e., $\{\equiv F e-O M\}=\{F e-M\})$, we obtain (Tessier et al., 1989):

$K_{\mathrm{Fe}-M}=\frac{N_{\mathrm{Fe}}{ }^{*} K_{\mathrm{Fe}-M}}{\left[H^{+}\right]^{x}}=\frac{\{\mathrm{Fe}-\mathrm{M}\}}{\{\mathrm{Fe}-\mathrm{Ox}\}\left[M^{z+}\right]}$

where $K_{F e-M}$ is a conditional equilibrium constant varying as a function of $\mathrm{pH}$, and $\{F e-M\}$ is the concentration of $M$ associated with the Fe oxyhydroxides.

If a similar approach is adopted for anion $(A)$, a conditional equilibrium constant $\left(K_{\mathrm{Fe}-\mathrm{A}}\right)$ is defined as follows (Belzile and Tessier, 1990):

$$
K_{\mathrm{Fe}-\mathrm{A}}=N_{\mathrm{Fe}}{ }^{*} K_{\mathrm{Fe}-\mathrm{A}}\left[H^{+}\right]^{x}=\frac{\{\mathrm{Fe}-\mathrm{A}\}}{\{\mathrm{Fe}-\mathrm{ox}\}\left[A^{y-}\right]}
$$

where $\{F e-A\}$ is the concentration of $A$ associated with the Fe oxyhydroxides and $A^{y-}$ is the freeanion concentration.

Values of $K_{\mathrm{Fe}-M}$ were obtained for $\mathrm{M}^{\mathrm{z}}=\mathrm{Ag}^{+}, \mathrm{Ca}^{2+}, \mathrm{Cd}^{2+}, \mathrm{Cu}^{2+}, \mathrm{Hg}^{2+}, \mathrm{MeHg}^{+}, \mathrm{Mg}^{2+}, \mathrm{Pb}^{2+}$ and $\mathrm{Zn}^{2+}$, and $K_{\mathrm{Fe}-\mathrm{A}}$ values for $A^{y^{-}=} \mathrm{AsO}_{4}{ }^{3-}, \mathrm{MoO}_{4}{ }^{2-}$ and $\mathrm{Sb}(\mathrm{OH})_{6}{ }^{-}$by introducing into equation (3) or (4) the free-ion activities given in Table 2 and the molar ratios M/Fe or $A / F e$ given in Table 3; by doing this, 
it is implicitly assumed that the measured molar ratios $M / F e$ and $A / F e$ corresponded to $\{F e-M\} /\{F e-O x\}$ and $\{F e-A\} /\{F e-o x\}$, respectively, i.e., that the trace elements in the authigenic material were entirely associated with Fe oxyhydroxides. These overall conditional equilibrium constants (hereafter called measured equilibrium constants and represented as ${ }^{m} K_{F e-M}$ or ${ }^{m} K_{F e-A}$ ) can be compared to the overall conditional equilibrium constants predicted (hereafter called predicted equilibrium constants and represented as ${ }^{p} K_{\mathrm{Fe}-\mathrm{M}}$ or ${ }^{p} \mathrm{~K}_{\mathrm{Fe}-\mathrm{A}}$ ) by the surface complexation model (SCM) under Lake Tantaré geochemical conditions using the intrinsic surface complexation constants $\left(K^{\text {int }}\right)$ given in Table 4. Formulation of predicted equilibrium constants is also given by Eq. 3 and 4 , but with the ratios $\{F e-M\} /\{F e-O x\}$ and $\{F e-A\} /\{F e-o x\}$ being predicted by the SCM rather than being measured. In the calculation of ${ }^{p} K_{\mathrm{Fe}-\mathrm{M}}$ or ${ }^{p} \mathrm{~K}_{\mathrm{Fe}-\mathrm{A}}$, a calculation with the two-layer version (DLM; e.g., Dzombak and Morel, 1990) of the surface complexation model was first run, using as input the ambient concentrations of dissolved major ions in Lake Tantaré water and assuming adsorptive equilibrium of ferrihydrite with the free-ion activities given in Table 2 at the $\mathrm{pH}$ of Lake Tantaré to obtain the $\{F e-M\} /\{F e-o x\}$ and $\{F e-A\} /\{F e-o x\}$ ratios predicted by the DLM. In calculating the ratio for all cations, the code MINEQL+ (Schecher and McAvoy, 1998) was used which contains in its database the surface characteristics of ferrihydrite (specific surface area of 600 $\mathrm{m}^{2} \mathrm{~g}^{-1}$; concentrations of strong and weak sites of $5 \times 10^{-3} \mathrm{~mol} \mathrm{~mol}^{-1}$ of ferrihydrite and $0.2 \mathrm{~mol} \mathrm{~mol}^{-1}$ of ferrihydrite, respectively) used by Dzombak and Morel (1990) to extract intrinsic adsorption constants $\left(K^{\text {int }}\right)$. The $K^{\text {int }}$ values used in the calculations were those proposed by Dzombak and Morel (1990) for the binding of $\mathrm{H}^{+}, \mathrm{Ca}^{2+}, \mathrm{Cd}^{2+}, \mathrm{Cu}^{2+}$, and $\mathrm{Zn}^{2+}$ to strong and weak adsorption sites and for the binding of $\mathrm{Ag}^{+}, \mathrm{Mg}^{2+}$ and $\mathrm{Pb}^{2+}$ to strong adsorption sites (Table 4). The $K^{\text {int }}$ values for the adsorption of $\mathrm{Hg}$ were from Tiffreau et al. (1995); note that the calculations for $\mathrm{Hg}$, were done with the value of 0.029 mol sites per mol of Fe used by Tiffreau et al. (1995) for extracting their intrinsic constants. The missing $K^{\text {int }}$ values for the adsorption of $\mathrm{MeHg}^{+}$on the strong and weak adsorption sites of ferrihydrite (Table 4) and of $\mathrm{Ag}^{+}, \mathrm{Mg}^{2+}$ and $\mathrm{Pb}^{2+}$ on the weak adsorption sites were obtained from the following linear free-energy relationships (LFER; Dzombak and Morel, 1990):

Log $K^{\text {int }}$ (strong sites) $=1.17 \log K_{\mathrm{MOH}}-4.37$

and

$\log K^{\text {int }}$ (weak sites) $=1.299 \log K_{M O H}-7.89$

where $K_{\mathrm{MOH}}$ is the first hydrolysis constant of the cations; the required values of $\mathrm{K}_{\mathrm{MOH}}$ for $\mathrm{Ag}^{+}, \mathrm{Mg}^{2+}$ and $\mathrm{Pb}^{2+}$ are given in Dzombak and Morel (1990), whereas that for $\mathrm{MeHg}^{+}$is given in Table 1. The $K^{\text {int }}$ value for the adsorption of $\mathrm{Mg}^{2+}$ on strong adsorption sites could not be determined by LFER (Dzombak and Morel, 1990), and it was assumed that its value was identical to that of $\mathrm{Ca}^{2+}$. Also, no $K^{\text {int }}$ for the adsorption of $\ln ^{3+}$ was available and it was not possible to estimate any value with LFER; these linear free-energy relationships seem to work well with divalent cations but there are no certainties for trivalent cations such as $\mathrm{In}^{3+}$. It should be noted that the possible formation of ternary complexes ( $\equiv F e-O M L$, with $L$ being $\mathrm{HA}$ and $\mathrm{FA}$ ) at the surface of Fe oxyhydroxides is ignored, since no $K^{\text {int }}$ are available for the formation of these surface species. For the adsorption of anions, the adsorption calculations were also run with the code MINEQL+, but recent values of $K^{\text {int }}$ determined by Gustafsson (2003) and Dixit and Hering (2003) for $\mathrm{MoO}_{4}{ }^{2-}$ and $\mathrm{AsO}_{4}{ }^{3-}$, respectively, were used. The value of $K^{\text {int }}$ for $\mathrm{Sb}(\mathrm{OH})_{6}{ }^{-}$adsorption was that reported by Dzombak and Morel (1990), as obtained by LFER. The ratios $\{F e-M\} /\{F e-o x\}$ and $\{F e-A\} /\{F e-o x\}$ predicted by the SCM were then divided by $\left[\mathrm{M}^{\mathrm{z}}\right]$ or $\left[\mathrm{A}^{\mathrm{y}}\right]$ (Table 2) to yield the ${ }^{p} K_{\mathrm{Fe}-\mathrm{M}}$ values.

Figure 2 shows that the ${ }^{p} K_{\mathrm{Fe}-\mathrm{A}}$ values are slightly higher than the ${ }^{m} K_{\mathrm{Fe}-\mathrm{A}}$ values for the anions $\mathrm{AsO}_{4}{ }^{3-}$ and $\mathrm{MoO}_{4}{ }^{2-}$ and slightly lower for $\mathrm{Sb}(\mathrm{OH})_{6}{ }^{-}$. For the cations $\mathrm{Ag}^{+}, \mathrm{Ca}^{2+}, \mathrm{Cd}^{2+}, \mathrm{Cu}^{2+}, \mathrm{Mg}^{2+}, \mathrm{Pb}^{2+}$ and $\mathrm{Zn}^{2+}$, the measured $K_{\mathrm{Fe}-\mathrm{M}}\left({ }^{m} \mathrm{~K}_{\mathrm{Fe}-\mathrm{M}}\right)$ values are all higher than those predicted with the DLM 
$\left({ }^{p} K_{F e-M}\right)$ (Fig. 2). The most striking feature of Fig. 2 is, however, the fact that the measured $K_{F e-M}$ value for $\mathrm{Hg}$ exceeds by nearly 20 orders of magnitude the value predicted by surface complexation theory. Another interesting feature is that ${ }^{m} K_{\mathrm{Fe}-M}$ is about 100 -fold smaller than ${ }^{p} K_{\mathrm{Fe}-\mathrm{M}}$ for $\mathrm{MeHg}$, which is inconsistent with the trend that is observed for $\mathrm{Hg}$ and the other cations. This may be an artefact associated with the value attributed to either $K^{\text {int }}$ for the binding of $\mathrm{MeHg}^{+}$to ferrihydrite (Table 4) or to the formation constants of the MeHg complexes with HA and FA (Table 1). The $K^{\text {int }}$ value for MeHg binding to ferrihydrite was not extracted from adsorption experiments, but obtained from a LFER, which is a source of uncertainty. However, to make ${ }^{p} K_{\mathrm{Fe}-M}$ smaller than ${ }^{m} K_{\mathrm{Fe}-M}$ in Fig. 2, a decrease of $K^{\text {int }}$ (or of $K_{\mathrm{MOH}}$ ) value by about 3 orders of magnitude would be required, which is unreasonable. On the other hand, as mentioned by Tipping (2007), there is some doubt about the accuracy of the formation constant for $\mathrm{MeHg}$ complexes with humic substances because they were extracted from laboratory experiments covering a small range of $\mathrm{pH}$ and $\mathrm{MeHg}$ levels. If, for the calculation of MeHg speciation with WHAM 6, the parameters (formation constant of $10^{3.0}$ for $\mathrm{MeHg}$ complexes with both $\mathrm{HA}$ and $\mathrm{FA}$ and a $\Delta \mathrm{LK}_{2}$ value of 3.6) suggested before the recent revision of Tipping (2007) are used, then the activity of $\mathrm{MeHg}^{+}$becomes much smaller $\left(4.7 \times 10^{-24}\right.$ compared to $1.68 \times 10^{-14}$ reported in Table 2); as a result, the ${ }^{m} K_{\mathrm{Fe}-\mathrm{M}}$ value (open triangles in Fig. 2) becomes about 7 orders of magnitude larger than ${ }^{p} K_{\mathrm{Fe}-\mathrm{M}}$, a result more consistent with the behaviours of $\mathrm{Hg}$ and the other cations.

\subsubsection{Scenario 2: Binding of trace metals to the organic matter associated with the $\mathrm{Fe}$ oxyhydroxides}

To examine if organic matter present in the diagenetic material collected on Teflon sheets can play a dominant role in binding the trace metal, the conditional equilibrium constants for metal binding to the particulate organic matter (POM) associated with the diagenetic material $\left(K_{P O M-M}\right)$ were compared with the conditional equilibrium constants for metal binding to dissolved organic matter $\left(D O M ; K_{\text {DOM-M }}\right.$ ) (see Fig. 3). It was assumed that organic matter coatings in the diagenetic material behave similarly to DOM (Davis, 1984).

Reaction of the metals with the particulate organic matter coatings on the Fe oxyhydroxides can be described by the following simplified equation:

$\mathrm{FeL}+\mathrm{M}^{\mathrm{z+}}=\mathrm{FeLM}$

with the conditional constant

$$
K_{P O M-M}=\frac{\{F e L M\}}{\{F e L\}\left[M^{z+}\right]}
$$

where $\{F e L\}$ and $\{F e L M\}$ are the concentrations of metal binding sites of the organic matter collected on Teflon sheets and of metal complexed with that organic matter, respectively. Values of $K_{P O M-M}$ were estimated by dividing the mean metal/Fe molar ratios by the HS/Fe ratio (Table 3 ), which provided the quotient $\{F e L M\} /\{F e L\}$ required in equation (8). The latter value was then divided by $\left[\mathrm{M}^{z^{+}}\right]$(Table 2). The implicit assumption behind this treatment is that the trace metals in the authigenic material were entirely associated with the organic matter.

In a similar manner, a simplified reaction for metal binding to DOM is:

$L^{r-}+M^{z+}=M L^{z-r}$

with the conditional constant

$$
K_{D O M-M}=\frac{\left[M L^{z-r}\right]}{\left[L^{r-}\right]\left[M^{z+}\right]}
$$


where $\left[M L^{z-r}\right]$ and $\left[L^{r-}\right]$ are the concentration of metal complexed to DOM (assumed to be exclusively humic substances) and that of free metal binding sites of DOM, respectively. The values of $\left[M L^{z-r}\right]$ and $\left[\mathrm{M}^{z+}\right]$ (Table 2) required in equation (10) were obtained from metal speciation calculations, i.e., from the output of WHAM 6 . The total concentration of metal binding sites (i.e., $[L]_{T}$ ) was estimated by assuming that the abundance of metal binding sites for FA and $\mathrm{HA}$ are $7.1 \times 10^{-3} \mathrm{~mol}$ per $\mathrm{g}$ of FA and $4.9 \times 10^{-3} \mathrm{~mol}$ per $\mathrm{g}$ of $\mathrm{HA}$, respectively (Table 2 ); subtracting from $[L]_{\mathrm{T}}$ the concentrations of metals bound to DOM, as provided by the output of WHAM 6 , yielded $\left[L^{r-}\right]$ to be used in equation (10). Calculations were not done for $\mathrm{Ag}^{+}, \mathrm{AsO}_{4}{ }^{3-}, \mathrm{MoO}_{4}{ }^{2-}$ and $\mathrm{Sb}(\mathrm{OH})_{6}{ }^{-}$due to the non-availability of formation constants for the complexation of these trace elements with HA and FA.

Figure 3 shows that the estimates of $K_{P O M-M}$ are reasonably similar to those of $K_{D O M-M}$, even though rough assumptions were made. The values of $K_{P O M-M}$ for $\mathrm{Cd}, \mathrm{Cu}, \mathrm{Hg}, \mathrm{MeHg}$ and $\mathrm{Zn}$ differ from those of $K_{D O M-M}$ by less than $0.5 \log$ units and those of $\mathrm{Ca}$ by around 0.7 log units; slightly larger differences between 1.1 and 1.7 log units are only observed for In, $\mathrm{Mg}$ and $\mathrm{Pb}$.

\subsection{On the proportions of authigenic and organically-bound trace elements in surficial sediments}

To support the discussion on the major binding phases for the trace elements in surficial oxic sediments of Lake Tantaré (assumed to be the top $0.5-\mathrm{cm}$ layer), the concentrations of authigenic trace elements were estimated as well as the concentrations of trace elements possibly bound to the whole of the organic matter present in this sediment layer.

The concentrations of authigenic trace elements were obtained by multiplying the molar ratios TE/Fe given in Table 3 by the concentration of $\mathrm{Fe}$ oxyhydroxides ( $\{\mathrm{Fe}-\mathrm{OX}\}$ ) in the top $0.5 \mathrm{~cm}$ sediment layer. For this calculation, it was assumed that $\{F e-o x\}\left(1.55 \times 10^{-3} \mathrm{~mol} \mathrm{~g}^{-1}\right.$; Table 5$)$ was given by the excess $\{\mathrm{Fe}\}$ over the constant background Fe concentration below $15 \mathrm{~cm}$ depth in the sediments (Fig. 1a). According to these calculations, the sediment authigenic Fe oxyhydroxides and their associated organic matter could bind practically all As, Mo and Cd present in the top $0.5 \mathrm{~cm}$ layer of Lake Tantaré oxic sediments, significant proportions (15-55\%) of $\mathrm{Ag}, \mathrm{Cu}, \mathrm{In}, \mathrm{Pb}, \mathrm{Sb}$, and $\mathrm{Zn}$ and small proportions (1-5\%) of $\mathrm{MeHg}$ and $\mathrm{Hg}$ (Table 5). Upon sediment burial, the reductive dissolution of Fe oxyhydroxides should release their adsorbed trace elements and organic matter; some portion of these trace elements can become associated to other adsorption sites in close proximity whereas another portion can migrate in porewater.

The organic matter present in the top $0.5-\mathrm{cm}$ sediment layer has a very similar molar $\mathrm{C}_{\text {org }} / \mathrm{N}$ ratio (15.5; Table 5) to that found in the diagenetic material collected on Teflon sheets (15.3 \pm 3.4 ; Table 3 ), indicating a common source which, given the high $\mathrm{C}_{\text {org }} / \mathrm{N}$ values, is probably the watershed. The molar ratio $\left\{\mathrm{C}_{\text {org }}\right\} /\{F e-O x\}$ is, however, much larger in the sediment top layer (13; Table 5) than in the diagenetic material (2.6 \pm 0.3 ; Table 3$)$, which indicates that only a small fraction (around $20 \%)$ of the organic matter is associated with the Fe oxyhydroxides in Lake Tantare sediments. The remaining organic matter is likely present as organic coatings on other mineral phases than Fe oxyhydroxides and as discrete particles. Thus, the maximum concentration of cationic trace metals bound to sedimentary organic matter, was estimated by multiplying the $T E / C_{\text {org }}$ ratios given in Table 3 by the concentration of sedimentary organic matter given in Table 5. According to this calculation, sediment organic matter could bind all In present in the top $0.5-\mathrm{cm}$ sediment layer, significant proportions (30-65\%) of $\mathrm{Hg}, \mathrm{Cu}$, and $\mathrm{Zn}$, small proportions (7\%) of $\mathrm{MeHg}$, but unrealistically high proportions (300-400\%) of $\mathrm{Cd}$ and $\mathrm{Pb}$ (Table 5).

\subsection{Association mode of the trace elements to Lake Tantaré oxic sediments}

Results obtained from the present research combined with those of other studies reporting the vertical distributions of trace elements in sediments and sediment porewaters at the same site are used below to identify which sedimentary phases the investigated elements are likely associated with Lake Tantaré oxic sediments. For example, agreement between measured and 
predicted conditional constants for the association of a given element with either Fe oxyhydroxides (Fig. 2) or organic matter (Fig. 3) in the diagenetic material is taken as an indication that this element is associated with that solid phase. Realistic predictions of the trace element concentration in the oxic layer of the sediments (Table 5 ) based on the $T E / F e$ and $T E / C_{\text {org }}$ ratios measured in the diagenetic material can also be used to reveal the most important binding phase. Furthermore, the occurrence of an enrichment for a given element in surface sediments that is coincidental with the Fe-enriched layer (Fig. 1a) is also a strong sign that the element is bound to authigenic Fe oxyhydroxides. Lastly, a correlation between the porewater concentrations of Fe and those of a trace element over the depth interval where Fe is recycled to form authigenic Fe oxyhydroxides (-2 $\mathrm{cm}$ to $3 \mathrm{~cm}$; Fig $1 \mathrm{~b}$ ) represents another indication that this trace element becomes associated with the authigenic Fe oxyhydroxides. This would be true even if the profile of this element in the solidphase does not exhibit any enrichment at the sediment surface. Indeed, porewater profiles of trace elements are more sensitive indicators of reactions involving the element than are their solid phase counterpart; they thus more easily reveal reactions that otherwise would remain unperceived.

\subsubsection{The anionic trace elements $\mathrm{AsO}_{4}{ }^{3-}$ and $\mathrm{MoO}_{4}{ }^{2-}$ and $\mathrm{Sb}(\mathrm{OH})_{6}{ }^{-}$}

Figure 2 shows that the $K_{\mathrm{Fe}-\mathrm{A}}$ values for the anions $\mathrm{AsO}_{4}{ }^{3-}$ and $\mathrm{MoO}_{4}{ }^{2-}$ fall close to the $1: 1$ line, suggesting that these two anions were bound to the Fe oxyhydroxides present in the Fe-rich diagenetic material collected on Teflon sheets. The values of ${ }^{p} K_{\mathrm{Fe}-\mathrm{A}}\left(10^{12.81}\right.$ for $\mathrm{AsO}_{4}{ }^{3-}$ and $10^{5.71}$ for $\left.\mathrm{MoO}_{4}{ }^{2-}\right)$ are slightly higher by a factor of $2.4-2.9$ than those of ${ }^{m} K_{\mathrm{Fe}-\mathrm{A}}\left(10^{12.35}\right.$ for $\mathrm{AsO}_{4}{ }^{3-}$ and $10^{5.33}$ for $\mathrm{MoO}_{4}{ }^{2-}$ ). A strong adsorption of these two anions onto $\mathrm{Fe}$ oxyhydroxides in Lake Tantaré sediments is supported by the occurrence of sharp $\{\mathrm{Mo}\}$ and $\{$ As\} surface maxima in the sediments of this lake which are similar in shape to that of $\{\mathrm{Fe}\}$ shown in Fig. 1a and by the close parallelism between porewater [Mo] and [As] profiles and those of [Fe] shown in Fig. 1b (Chappaz et al., 2008; Couture et al., 2008). The lower observed than predicted Mo and As adsorption in Lake Tantaré sediments has been attributed to the fact that Mo and As adsorption equilibrium is not reached because natural organic matter inhibits the rate of adsorption of these two anions onto $\mathrm{Fe}$ oxyhydroxides (Chappaz et al., 2008; Couture et al., 2010a). This assertion is supported by laboratory experiments showing that the addition of natural organic matter decreased the rate of As adsorption onto hematite by several orders of magnitude (Redman et al., 2002). Table 5 indicates that most of the As and Mo in the surficial sediment should be authigenic.

For the anion $\mathrm{Sb}(\mathrm{OH})_{6}^{-}$, the ${ }^{m} K_{F e-A}$ value $\left(10^{4.31}\right)$ is about 4 times higher than that of ${ }^{p} K_{\mathrm{Fe}-\mathrm{A}}\left(10^{3.66}\right)$. The difference between measured and predicted adsorption of $\mathrm{Sb}(\mathrm{OH})_{6}{ }^{-}$may be due to the fact that the $K^{\text {int }}$ values used in the calculations with the DLM were not measured but derived from LFER; relatively large errors can result from such interpolations. Bernatchez (2009) reported that the porewater [Sb] profiles at the same sampling site in Lake Tantaré paralleled those of [Fe] over the depth interval where Fe oxyhydroxides are recycled, thus supporting the association of Sb with authigenic Fe oxyhydroxides. However, there is no Sb enrichment in the sediment surface layer as observed for the other anions and for Fe, likely due to the lower "mobility" of $\mathrm{Sb}$ in the sediments (Bernatchez, 2009). Thus, Sb appears to be associated with the authigenic Fe oxyhydroxides but in lesser proportions than As and Mo. Consistently, Fig. 2 indicates that, adsorption of $\mathrm{Sb}$ to $\mathrm{Fe}$ oxyhydroxides is weaker than that of Mo or As and Table 5 reveals that only about $30 \%$ of total Sb in surficial sediment should be authigenic.

3.4.2. The cationic trace elements $\mathrm{Ag}^{+}, \mathrm{Ca}^{2+}, \mathrm{Cd}^{2+}, \mathrm{Cu}^{2+}, \mathrm{Hg}^{2+}, \mathrm{In}^{3+}, \mathrm{MeHg}^{+}, \mathrm{Mg}^{2+}, \mathrm{Pb}^{2+}$ and $\mathrm{Zn}^{2+}$ Interestingly, the ratio between measured and predicted $\mathrm{K}_{\mathrm{Fe}-\mathrm{M}}$ values increases inversely with affinity of the cations $\mathrm{Ca}^{2+}, \mathrm{Cd}^{2+}, \mathrm{Cu}^{2+}, \mathrm{Mg}^{2+}, \mathrm{Pb}^{2+}$ and $\mathrm{Zn}^{2+}$ for the Fe oxyhydroxides collected on 
Teflon sheets (Fig. 2). For example, the ${ }^{m} K_{\mathrm{Fe}-M} /{ }^{p} K_{\mathrm{Fe}-M}$ ratio is 8 for $\mathrm{Pb}^{2+}$, but reaches values of 3 $\times 10^{4}$ and $6 \times 10^{4}$ for $\mathrm{Ca}^{2+}$ and $\mathrm{Mg}^{2+}$, respectively. Similar behaviour has been reported for diagenetic material collected in the low $\mathrm{pH}$ Lake Clearwater $(\mathrm{pH}=4.8)$ and has been ascribed to complexation of these metals with organic matter adsorbed at the surface of the Fe oxyhydroxides rather than to the hydroxyl groups of the Fe oxyhydroxides (Tessier et al., 1996). The latter interpretation also applies to the diagenetic material collected in Lake Tantaré, and it is supported by the close agreement between $K_{P O M-M}$ and $K_{D O M-M}$ for $\mathrm{Ca}^{2+}, \mathrm{Cd}^{2+}, \mathrm{Cu}^{2+}, \mathrm{Mg}^{2+}$ and $\mathrm{Zn}^{2+}(\mathrm{Fig}$. 3). The inference of preferential binding of these cations to natural organic matter (NOM) in the diagenetic material is also valid for oxic sediments, where the ratio $\left\{\mathrm{C}_{\text {org }}\right\} /\{\mathrm{Fe}-\mathrm{ox}\}$ is much larger (Tables 3 and 5). This is supported by the absence of surface maxima corresponding to that of $\{\mathrm{Fe}\}$ (Fig. 1a) in the solid-phase profiles of Cd, Ca or Mg (Alfaro-De la Torre and Tessier, 2002) and Zn (Carignan and Tessier, 1985), and by the absence of any significant correlation between porewater [Fe] and [Cd] (Alfaro-De la Torre and Tessier, 2002) or [Zn] (Carignan and Tessier, 1985). However, it should be noted that $\mathrm{Pb}^{2+}$ is an exception among these cations, given that it shows a slightly better agreement between ${ }^{m} K_{\mathrm{Fe}-M}$ and ${ }^{p} K_{\mathrm{Fe}-M}$ (Fig. 2) than between $K_{P O M-M}$ and $K_{D O M-M}$ (Fig. 3) and that the $[\mathrm{Pb}]$ porewater profiles parallel those of [Fe] (Gallon et al., 2004). Furthermore, concentrations of organically-bound $\mathrm{Pb}$ in the surficial sediment, predicted from the $\mathrm{Pb} / \mathrm{C}_{\text {org }}$ measured in the diagenetic material collected on Teflon sheets, are unrealistic, being much larger than total $\{\mathrm{Pb}\}$ (Table 5). Thus, collectively, the observations point consistently to the preferential binding of $\mathrm{Ca}^{2+}$, $\mathrm{Cd}^{2+}, \mathrm{Cu}^{2+}, \mathrm{Mg}^{2+}$ and $\mathrm{Zn}^{2+}$ to organic matter and $\mathrm{Pb}^{2+}$ to the authigenic Fe oxyhydroxides.

The mode of association of $\mathrm{Ag}^{+}$to Lake Tantaré sediment is more difficult to ascertain. The ${ }^{m} K_{\mathrm{Fe}-\mathrm{M}} /{ }^{p} K_{\mathrm{Fe}-\mathrm{M}}$ ratio larger than 1 found for this metal (Fig. 2) can be interpreted as a sign of preferential binding to humic substances in the authigenic material, like for other cations. Also, no correlations were observed between porewater [Ag] and [Fe] profiles (Quirion, 2004), suggesting that $\mathrm{Ag}^{+}$is not bound to Fe oxyhydroxides in the oxic sediment. However, to the best of the authors' knowledge, there is no available binding constant for this metal with humic substances that can be used to verify its binding to NOM. For $\operatorname{~In~}^{3+}$, the similarities in values between $K_{P O M-M}$ and $K_{D O M-M}$ (Fig. 3 ) and between measured and organically-bound $\{\ln \}$ (Table 5) indicate that this metal is mostly bound to humic substances in both the authigenic material and the sediment.

Regarding $\mathrm{Hg}^{2+}$, the close agreement between $K_{P O M-M}$ and $K_{D O M-M}$ (Fig. 3) as well as the much larger ${ }^{m} K_{\mathrm{Fe}-\mathrm{M}}$ than ${ }^{p} \mathrm{~K}_{\mathrm{Fe}-\mathrm{M}}$ values (Fig. 2) indicate clearly that this metal is bound to the functional groups of organic matter and not to the hydroxyl groups of the Fe oxyhydroxides in the material collected with Teflon sheets. It is inferred that this preference of $\mathrm{Hg}^{2+}$ for $\mathrm{NOM}$ is also valid for the oxic sediment, and this interpretation is consistent with the absence of both a sharp $\{\mathrm{Hg}\}$ maximum at the sediment surface and correlation between $[\mathrm{Hg}]$ and $[\mathrm{Fe}]$ depth profiles at the same site (Feyte et al., 2010). The interpretation of $\mathrm{Hg}$ being preferentially bound to humic substances is also supported by the correlations found in several studies between the sedimentary concentrations of $\mathrm{Hg}$ and organic matter (e.g., Hollweg et al., 2009; Hammerschmidt and Fitzgerald, 2004). Table 5 indicates that, despite the strong affinity of $\mathrm{Hg}$ for organic matter (Fig. 3), only about $30 \%$ of total sediment $\mathrm{Hg}$ should be organically-bound. The remaining sediment $\mathrm{Hg}$ should be present in refractory forms or as elemental $\mathrm{Hg}$ (Bouffard and Amyot, 2009).

Lastly, the relatively good agreement between $K_{P O M-M}$ and $K_{D O M-M}$ for $\mathrm{MeHg}$ (Fig. 3), despite the large uncertainties in its binding constants with $\mathrm{HA}$ and FA, suggests that this toxic compound has a greater affinity for the organic matter associated with Fe oxyhydroxides in the authigenic material than for the hydroxyl groups of these compounds. A similar interpretation for the oxic sediments is supported by the absence of any correlation between porewater [MeHg] and [Fe] (Feyte et al., 2010). Furthermore, the interpretation that $\mathrm{MeHg}$ is bound to organic matter is consistent with observations in marine and estuarine sediments suggesting that organic matter exerts a major 
control on the MeHg distribution in surface deposits (e.g., Lambertsson and Nilsson, 2006; Sunderland et al., 2006).

\section{Conclusions}

The analyses of Lake Tantaré diagenetic material, sediment and bottom water, combined with previous results on porewater and solid phases at the same site, clarify whether Fe oxyhydroxides or natural organic matter bind a number of trace elements in oxic sediments. Collectively, these data are coherent with the scenario that in the oxic sediments of this lake: i) the oxyanions $\mathrm{AsO}_{4}{ }^{3-}$, $\mathrm{MoO}_{4}{ }^{2-}$ and $\mathrm{Sb}(\mathrm{OH})_{6}{ }^{-}$are essentially associated with $\mathrm{Fe}$ oxyhydroxides; and ii) the cations $\mathrm{Ca}^{2+}$, $\mathrm{Cd}^{2+}, \mathrm{Cu}^{2+}, \mathrm{Mg}^{2+}, \mathrm{Hg}^{2+}, \mathrm{MeHg}^{+}, \mathrm{Mg}^{2+}, \mathrm{In}^{3+}, \mathrm{Zn}^{2+}$, and probably $\mathrm{Ag}^{+}$, are preferentially bound to the organic matter and $\mathrm{Pb}^{2+}$ to the Fe oxyhydroxides.

However, further investigations need to be carried out in environments exhibiting a larger range of geochemical conditions before generalizations can be made about the relative binding affinity of trace elements to Fe oxyhydroxides and natural organic matter. For example, Tessier et al. (1996) have shown that at higher lake $\mathrm{pH}$ values, the affinity of $\mathrm{Cd}^{2+}, \mathrm{Cu}^{2+}, \mathrm{Ni}^{2+}$ and $\mathrm{Zn}^{2+}$ for $\mathrm{Fe}$ oxyhydroxides can overcome that for organic matter.

The data (Fig. 3) also confirm the affinity of $\mathrm{Hg}^{2+}$ for natural organic matter, which has been suggested in field studies on the basis of significant linear correlations between $\{\mathrm{Hg}\}$ and $\left\{\mathrm{C}_{\text {org }}\right\}$. In agreement with the present observations, the generally low determination coefficients $\left(r^{2}\right)$ found for these correlations could be due to the fact that, despite the strong affinity of $\mathrm{Hg}$ for organic matter, only a small proportion ( $-30 \%$ in Lake Tantaré oxic sediments) of total $\mathrm{Hg}$ is effectively organicallybound, most of the $\mathrm{Hg}$ being present in the sediments in refractory forms. As a last point, it should be noted that the excellent agreement found between $K_{P O M-M}$ and $K_{D O M-M}$ for $\mathrm{Hg}^{2+}$ (Fig. 3 ) lends support to the revised formation constants of $\mathrm{Hg}$ complexes with humic substances provided by Tipping (2007); however, a similar conclusion cannot be drawn for $\mathrm{MeHg}^{+}$.

\section{Acknowledgments}

Financial support from the Natural Sciences and Engineering Research Council of Canada, the Fonds de Recherche sur la Nature et les Technologies du Québec and the Ministère des Relations Internationales du Québec (Coopération France-Québec) are acknowledged. We thank L. Rancourt, R. Rodrigue and P. Fournier for their technical assistance. Permission from the Québec Ministère de l'Environnement to work in the Tantaré Ecological Reserve is gratefully acknowledged.

\section{References}

Adelson, J.M., Helz, G.R., Miller, C.V., 2001. Reconstructing the rise of recent coastal anoxia; molybdenum in Chesapeake Bay sediments. Geochim. Cosmochim. Acta 65, 237-252.

Alfaro-De La Torre, C., Tessier, A., 2002. Cadmium deposition and mobility in the sediments of an acidic oligotrophic lake. Geochim. Cosmochim. Acta 66, 3549-3562.

Bacon, J.R., Davidson, C.M., 2008. Is there a future for sequential chemical extraction? Analyst 133, 25-46.

Belzile, N., Tessier, A., 1990. Interactions between arsenic and iron oxyhydroxides in lacustrine sediments. Geochim. Cosmochim. Acta 54, 103-109. 
Belzile, N., De Vitre, R.R., Tessier, A., 1989. In situ collection of diagenetic iron and manganese oxhydroxides from natural sediments. Nature 340, 376-377.

Bernatchez, M.-N., 2009. Dépôt et mobilité de l'antimoine dans les sédiments de lacs du Bouclier canadien. MSc thesis No 1163, INRS-ETE, Université du Québec.

Bloom, N.S., Fitzgerald, W.F., 1988. Determination of volatile mercury species at picogram level by low temperature gas chromatography with cold-vapour atomic fluorescence detection. Anal. Chim. Acta 28, 151-161.

Bothe, J.V., Brown, P.W., 1999. The stabilities of calcium arsenates at $23 \pm 1$ degrees C. J. Hazard. Mater. 69, 197-207.

Bouffard, A., Amyot, M., 2009. Importance of elemental mercury in lake sediments. Chemosphere 74, 1098-1103.

Buffle, J., 1988. Complexation Reactions in Aquatic Systems. Ellis Horwood Ltd, Chichester.

Carbonaro, R.F., Di Toro, D.M., 2007. Linear free energy relationships for metal-ligand complexation: Monodentate binding to negatively-charged oxygen donor atoms. Geochim. Cosmochim. Acta 71, 3958-3968.

Carignan, R., Tessier, A., 1985. Zinc deposition in acid lakes: the role of diffusion. Science 228, 1524-1526.

Carignan, R., Rapin, F., Tessier, A., 1985. Sediment porewater sampling for metal analysis: a comparison of techniques. Geochim. Cosmochim. Acta 49, 2493-2497.

Chao, T.T., Zhou, L., 1983. Extraction techniques for selective dissolution of amorphous iron oxides from soils and sediments. Soil Sci. Soc. Am. J. 47, 225-232.

Chappaz, A., 2008. Géochimie du molybdène, du rhénium et de l'uranium dans les sédiments de lacs du Bouclier canadien et des Appalaches. PhD thesis No 424, INRS-ETE, Université du Québec.

Chappaz, A., Gobeil, C., Tessier, A., 2008. Geochemical and anthropogenic enrichments of Mo in sediments from perennially oxic and seasonally anoxic lakes in Eastern Canada. Geochim. Cosmochim. Acta 72, 170-184.

Cossa, D., Averty, B., Bretaudeau, J., Senard, A.-S., 2003. Spéciation du mercure dissous dans les eaux marines. Méthodes d'analyse en milieu marin. Co-édition Ifremer et Ministère de l'Ecologie et du Développement Durable. ISBN 2-84433-125-4.

Cossa, D., Averty, B., Pirrone, N., 2009. The origin of methylmercury in open Mediterranean waters. Limnol. Oceanog. 54, 837-844.

Cossa, D., Coquery, M., Nakhlé, K., Claisse, D., 2002. Dosage du mercure total et du monométhylmercure dans les organismes et les sédiments marins. Méthodes d'analyse en milieu marin. Editions Ifremer. ISBN 2-84433-105-X..

Couture, R.M., Gobeil, C., Tessier, A., 2008. Chronology of atmospheric deposition of arsenic inferred from reconstructed sedimentary records. Environ. Sci. Technol. 42, 6508-6513.

Couture, R.M., Gobeil, C., Tessier, A., 2010a. Arsenic, iron and sulfure co-diagenesis in lake sediments. Geochim. Cosmochim. Acta 74, 1238-1255.

Couture, R.M., Shafei, B., Van Cappellen, P., Tessier, A. Gobeil, C., 2010b. Non-steady state modeling of arsenic diagenesis in lake sediments. Environ. Sci. Technol. 44, 197-203.

Crusius, J., Calvert, S.E., Pedersen, T.F., Sage, D., 1996. Rhenium and molybdenum enrichments in sediments as indicators of oxic, suboxic and sulfidic conditions of deposition. Earth Planet. Sci. Lett. 145, 65-78.

Danielsson, A., Carman, R., Rahm, L., Aigars, J., 1998. Spatial estimation of nutrient distributions in the Gulf of Riga sediments using cokriging. Estuar. Coast. Shelf Sci. 46, 713-722.

Davis, J.A., 1984. Adsorption of natural organic matter at the oxide/water interface. Geochim. Cosmochim. Acta 46, 2381-2393.

Davis, J.A., Kent D.B., 1990. Surface complexation modeling in aqueous geochemistry. Rev. Mineral. 23, 177-260. 
De Robertis, A., Foti, C., Patane, G., Sammartano, S., 1998. Hydrolysis of (CH3)Hg+ in different ionic media: Salt effects and complex formation. J. Chem. Eng. Data 43, 957-960.

Dixit, S., Hering, J.G., 2003. Comparison of arsenic(V) and arsenic(III) sorption onto iron oxide minerals: implications for arsenic mobility. Environ. Sci. Technol. 37, 4182-4189.

Dzombak, D., Morel, F.M.M., 1990. Surface Complexation Modeling: Hydrous Ferric Oxide. Wiley, New York.

Essington, M.E., 1992. Formation of calcium and magnesium molybdate complexes in dilute aqueous solutions. Soil Sci. Soc. Am. J. 56, 1124-1127.

Feyte, S., Gobeil, C., Tessier, A., Cossa, D., 2010. History of atmospheric deposition of mercury reconstructed from sedimentary records corrected for diagenesis, in prep.

Filella, M., May P.M., 2003. Computer simulation of the low-molecular-weight inorganic species distribution of antimony(III) and antimony(V) in natural waters. Geochim. Cosmochim. Acta 67, 4013-4031.

Fortin, D., Leppard, G.G., Tessier, A., 1993. Characteristics of lacustrine diagenetic iron oxyhydroxides. Geochim. Cosmochim. Acta 57, 4391-4404.

Gallon, C., Tessier, A., Gobeil, C., Alfaro-De La Torre, M.C., 2004. Modeling diagenesis of lead in sediments of a Canadian Shield lake. Geochim. Cosmochim. Acta 68, 3531-3545.

Gu, B., Schmitt, J., Chen, Z., Liang, L., McCarthy, J.F., 1994. Adsorption and desorption of natural organic matter on iron oxide: Mechanisms and models. Environ. Sci. Technol. 28, 38-46.

Gustafsson, J.P., 2003. Modelling molybdate and tungstate adsorption to ferrihydrite. Chem. Geol. 200, 105-115.

Hamilton-Taylor, J., Willis, M., Reynold, C. S., 1984. Depositional fluxes of metals and phytoplankton in Windermere as measured by sediment traps. Limnol. Oceanog. 29, 695-710.

Hammerschmidt, C.R., Fitzgerald, W.F., 2004. Geochemical controls on the production and distribution of methylmercury in near-shore marine sediments. Environ. Sci. Technol. 38, 14871495.

Hammerschmidt, C.R., Fitzgerald, W.F., 2006. Methylmercury cycling in sediments on the continental shelf of southern New England. Geochim. Cosmochim. Acta 70, 918-930.

Hollweg, T.A., Gilmour, C.C., Mason, R.P., 2009. Methylmercury production in sediments of Chesapeake Bay and the mid-Atlantic continental margin. Mar. Chem. 114, 86-101.

International Union of Pure and Applied Chemistry (Ed.), 2001. The IUPAC Stability constants database, Sourby Old Farm, Timble, Otley, Yorks, UK: Academic Software.

Jenne, E.A., 1968. Controls on $\mathrm{Mn}, \mathrm{Fe}, \mathrm{Co}, \mathrm{Ni}, \mathrm{Cu}$, and $\mathrm{Zn}$ concentrations in soils and water: The significant role of hydrous Mn and Fe oxides. In: Gould, R. F. (Ed.), Trace Inorganics in Water. Adv. Chem. Ser. No 73. Am. Chem. Soc. Washington, D.C., 337-387.

Krachler, M., Shotyk, W., 2004. Natural and anthropogenic enrichments of molybdenum, thorium, and uranium in a complete peat bog profile, Jura Mountains, Switzerland. J. Environ. Monitor. 6, 418-426.

Laforte, L., 2005. Thallium et Indium dans les sédiments de deux lacs du Bouclier Canadien: sources, géochimie et potentiel comme traceurs. MSc thesis No 910, INRS-ETE, Université du Québec.

Laforte, L., Tessier, A., Gobeil, C., Carignan, R., 2005. Thallium diagenesis in lake sediments. Geochim. Cosmochim. Acta 69, 5295-5306.

Lambertsson, L., Nilsson, M., 2006. Organic material: the primary control on mercury methylation and ambient methylmercury concentrations in estuarine sediments. Environ. Sci. Technol. 40, 1822-1829.

Leermakers, M., Galletti, S., De Galan, S., Brion, N., Baeyens, W., 2001. Mercury in the Southern North Sea and Scheldt estuary. Mar. Chem. 75, 229-248.

Linge, K.L., 2008. Methods for investigating trace element binding in sediments. Crit. Rev. Environ. Sci. Technol. 38, 165-196. 
Loux, N.T., 2007. An assessment of thermodynamic reaction constants for simulating aqueous environmental monomethylmercury speciation. Chem. Speciation Bioavail. 19, 183-196.

Luoma, S.N., Bryan, G.W., 1981. A statistical assessment of the form of trace metals in oxidized estuarine sediments employing chemical extractants. Sci. Total Environ. 17, 165-196.

Malcolm, R.L., 1985. Geochemistry of stream fulvic and humic substances. In: Aiken, G.R., McKnight, D.M., Wershaw, R. L., MacCarthy, P. (Eds.), Humic Substances in Soil, Sediment and Water. Geochemistry, Isolation and Characterization. Wiley-Interscience, New York, 181-209.

Martell, A.E., Smith, R.M., 2001. NIST Critically Selected Stability Constants of Metal Complexes, version 6 Gaithersburg, Maryland: National Institute of Standards and Technology.

McKnight, D.M., Bencala, K.E., Zellweger, G.W., Aiken, G.R., Feder, G.L., Thorn, K.A., 1992. Sorption of dissolved organic carbon by hydrous aluminum and iron oxides occurring at the confluence of Deer Creek with the Snake River, Summit County, Colorado. Environ. Sci. Technol. 26, 1388-1396.

Mulla, F., Marsicano, F., Nakani, B.S., Hancock, R.D., 1985. Stability of ammonia complexes that are unstable to hydrolysis in water. Inorg. Chem. 24, 3076-3080.

Murata, T., 1991. Synchrotron radiation for structure analysis - EXAFS and XANES. Microchim. Acta 104, 435-444.

Nordstrom, D.K., Archer, D.G., 2003. Arsenic thermodynamic data and environmental geochemistry. In: Welch, A.H., Stollenwerk, K.G. (Eds), Arsenic in Ground Water, Geochemistry and Occurrence. Kluwer Academic Publications, Norwell, MA., 1-25.

Pacyna, J.M., Pacyna, E.G., 2001. An assessment of global and regional emissions of trace metals to the atmosphere from anthropogenic sources worldwide. Environ. Rev. 9, 269-298.

Parsons, J.G., Aldrich, M.V., Gardea-Torresdey, J.L., 2002. Environmental and biological applications of extended X-ray absorption fine structure (EXAFS) and X-ray absorption near edge structure (XANES) spectroscopies. Appl. Spectrosc. Rev. 37, 187-222.

Powell, K.J., Brown, P.L., Byrne, R.H., Gajda, T., Hefter, G., Sjöberg, S., Wanner, H., 2005. Chemical speciation of environmentally significant heavy metals with inorganic ligands. Part 1: The $\mathrm{Hg}^{2+}-\mathrm{Cl}^{-}, \mathrm{OH}^{-}, \mathrm{CO}_{3}{ }^{2-}, \mathrm{SO}_{4}{ }^{2-}$, and $\mathrm{PO}_{4}{ }^{2-}$ aqueous systems. Pure Appl. Chem. 77, 739-800.

Quirion, R., 2004. Déposition et mobilité de Ag dans les sédiments de lacs du Bouclier Canadien. MSc thesis No 869, INRS-ETE, Université du Québec.

Rabenstein, D.L., Touranqueau, M.C., Evans, C.A., 1976. Proton magnetic resonnance and Raman spectroscopic studies of methylmercury(II) complexes of inorganic anions. Can. J. Chem. 54, 25172525.

Ranville, M.A., Flegal, A.R., 2005. Silver in the North Pacific. Geochem. Geophys. Geosyst., 6, Q03M01, doi:10.1029/2004GC000770.

Redfield, A.C., 1934. On the proportions of organic derivatives in seawater and their relation to the composition of plankton. In: Daniel, R.J. (Ed.), James Johnson Memorial Volume. Liverpool University Press, Liverpool.

Redman, A.D., Macalady, D.L., Ahmann, D., 2002. Natural organic matter affects arsenic speciation and sorption onto hematite. Environ. Sci. Technol. 36, 2889-2896.

Schecher, M.E., McAvoy, D., 1998. MINEQL+. Environmental Research Software.

Schlautman, M.A., Morgan, J.J., 1994. Adsorption of aquatic humic substances on colloidal-size aluminium oxide particles: Influence of solution chemistry. Geochim. Cosmochim. Acta 58, 42934303.

Schwertmann, U., Wagner, F., Knicker, H., 2005. Ferrihydrite-humic associations: Magnetic hyperfine interactions. Soil Sci. Soc. Am. J. 69, 1009-1015.

Sigg, L., Sturm, M., Kistler, D., 1987. Vertical transport of heavy metals by settling particles. Limnol. Oceanog. 32, 112-130.

Singer, D. M., Zachara, J.M., Brown, G.E., 2009. Uranium speciation as a function of depth in contaminated Hanford sediments - A micro-XRF, micro-XRD, and micro- and bulk-XAFS study. Environ. Sci. Technol. 43, 630-636. 
Smith, R.M., Martell, A.E., 1976. Critical Stability Constants: Inorganic Complexes. Vol 4. Plenum Press, New York.

Sposito, G., 1984. The Surface Chemistry of Soils. Oxford University Press, New York.

Stoichev, T., Rodriguez M.-D., R.C., Tessier, E., Amouroux, D., Donard, O.F.X., 2004. Improvement of analytical performances for mercury speciation by on-line derivatization, cryofocussing and atomic fluorescence spectrometry. Talanta 62, 433-438.

Sunderland, E.M., Gobas, F.A.P.C., Branfireun, B.A., Heyes, A., 2006. Environmental controls on the speciation and distribution of mercury in coastal sediments. Mar. Chem. 102, 111-123.

Tessier, A., Campbell, P.G.C., Bisson, M., 1979. Sequential extraction procedure for the speciation of particulate trace metals. Anal Chem. 51, 844-851.

Tessier, A, Carignan, R., Dubreuil, B., Rapin, F., 1989. Partitioning of zinc between the water column and the oxic sediments in lakes. Geochim. Cosmochim. Acta 53, 1511-1522.

Tessier, A., Fortin, D., Belzile, N., DeVitre, R.R., Leppard, G.G., 1996. Metal sorption to diagenetic iron and manganese oxyhydroxides and associated organic matter: Narrowing the gap between field and laboratory measurements. Geochim. Cosmochim. Acta 60, 387-404.

Tiffreau, C., Lützenkirchen, J., Behra, P., 1995. Modeling the adsorption of mercury(II) on (hydr)oxides. 1. Amorphous iron oxides and $\alpha$-quartz. J. Colloid Interface Sci. 172, 82-93.

Tipping, E., 1981. The adsorption of aquatic humic substances by iron oxides. Geochim. Cosmochim. Acta 45, 191-199.

Tipping, E., 1994. WHAM- A chemical equilibrium model and computer code for waters, sediments, and soils incorporating a discrete site/electrostatic model of ion-binding by humic substances. Comp. Geosci. 20, 973-1023.

Tipping, E., 1998. Humic ion-binding model VI: An improved description of the interactions of protons and metal ions with humic substances. Aquat. Geochem. 4, 3-48.

Tipping, E., 2002. Cation Binding by Humic Substances. Cambridge University Press, Cambridge. Tipping, E., 2007. Modelling the interactions of $\mathrm{Hg}(\mathrm{II})$ and methylmercury with humic substances using WHAM/Model VI. Appl. Geochem. 22, 1624-1635.

Tipping, E., Woof, C., Cooke, D., 1981. Iron oxide from a seasonally anoxic lake. Geochim. Cosmochim. Acta 45, 1411-1419.

Whiting, K.S., 1992. The thermodynamics and geochemistry of arsenic with application to subsurface waters at the Sharon Steel superfund site at Midwale, Utah. MSc Thesis T-4128, Colorado School of Mines, Golden, CO.

Yagasaki, A., Andersson, I., Pettersson, L., 1987. Multicomponent polyanions. 41. Potentiometric and ${ }^{31} \mathrm{P}$ NMR study of equilibria in the molybdophenylphophonate system in $0.6 \mathrm{M} \mathrm{Na}(\mathrm{Cl})$ medium. Inorg. Chem. 26, 3926-3933.

Zhao, F.J., Lehmann, J., Solomon, D., Fox, M.A., McGrath, S.P., 2006. Sulphur speciation and turnover in soils: Evidence from sulphur K-edge XANES spectroscopy and isotope dilution studies. Soil Biol. Biochem. 38, 1000-1007. 
Table 1. Formation constants $\left(25^{\circ} \mathrm{C}\right.$ and $\left.\mathrm{I}=0\right)$ used to update the WHAM 6 database for $\mathrm{Hg}, \mathrm{MeHg}$, $\mathrm{Ag}$, In, As, Mo and Sb speciation calculations. The symbols $\mathrm{R}_{\mathrm{HA}}{ }^{\mathrm{z}}$ and $\mathrm{R}_{\mathrm{FA}}{ }^{\mathrm{z}}$ represent the molecules of humic and fulvic acids, respectively.

\begin{tabular}{|c|c|c|}
\hline Reaction & $\log K$ & References \\
\hline $\begin{array}{l}\mathrm{Hg}^{2+}+\mathrm{OH}^{-}=\mathrm{HgOH}^{+} \\
\mathrm{Hg}^{2+}+2 \mathrm{OH}^{-}=\mathrm{Hg}(\mathrm{OH})_{2} \\
\mathrm{Hg}^{2+}+3 \mathrm{OH}^{-}=\mathrm{Hg}(\mathrm{OH})_{3}^{-} \\
\mathrm{Hg}^{2+}+\mathrm{OH}^{-}+\mathrm{Cl}^{-}=\mathrm{HgOHCl} \\
\mathrm{Hg}^{2+}+\mathrm{Cl}^{-}=\mathrm{HgCl}^{+} \\
\mathrm{Hg}^{2+}+2 \mathrm{Cl}^{-}=\mathrm{HgCl}_{2} \\
\mathrm{Hg}^{2+}+3 \mathrm{Cl}^{-}=\mathrm{HgCl}_{3}^{-} \\
\mathrm{Hg}^{2+}+4 \mathrm{Cl}^{-}=\mathrm{HgCl}_{4}^{2-} \\
\mathrm{Hg}^{2+}+\mathrm{SO}_{4}^{2-}=\mathrm{HgSO}_{4} \\
\mathrm{Hg}^{2+}+\mathrm{CO}_{3}^{2-}=\mathrm{HgCO}_{3} \\
\mathrm{Hg}^{2+}+\mathrm{OH}^{-}+\mathrm{CO}_{3}^{2-}=\mathrm{Hg}(\mathrm{OH}) \mathrm{CO}_{3}^{-} \\
\mathrm{Hg}^{2+}+\mathrm{H}^{+}+\mathrm{CO}_{3}^{2-}=\mathrm{HgHCO}_{3}^{+} \\
\mathrm{Hg}^{2+}+\mathrm{R}_{\mathrm{HA}^{2}}{ }^{2}=\mathrm{RHg}_{\mathrm{HA}} \\
\mathrm{Hg}^{2+}+\mathrm{R}_{\mathrm{FA}}{ }^{\mathrm{z}}=\mathrm{RHg}_{\mathrm{FA}}\end{array}$ & $\begin{array}{l}\mathbf{H g} \\
10.6 \\
22.02 \\
20.9 \\
18.27 \\
7.3 \\
14.0 \\
14.93 \\
15.5 \\
2.6 \\
11.51 \\
19.34 \\
15.84 \\
3.6 \\
3.1\end{array}$ & $\begin{array}{l}\text { Powell et al. (2005) } \\
\text { Powell et al. (2005) } \\
\text { Powell et al. (2005) } \\
\text { Powell et al. (2005) } \\
\text { Powell et al. (2005) } \\
\text { Powell et al. (2005) } \\
\text { Powell et al. (2005) } \\
\text { Powell et al. (2005) } \\
\text { Powell et al. (2005) } \\
\text { Powell et al. (2005) } \\
\text { Powell et al. (2005) } \\
\text { Powell et al. (2005) } \\
\text { Tipping (2007) } \\
\text { Tipping (2007) }\end{array}$ \\
\hline 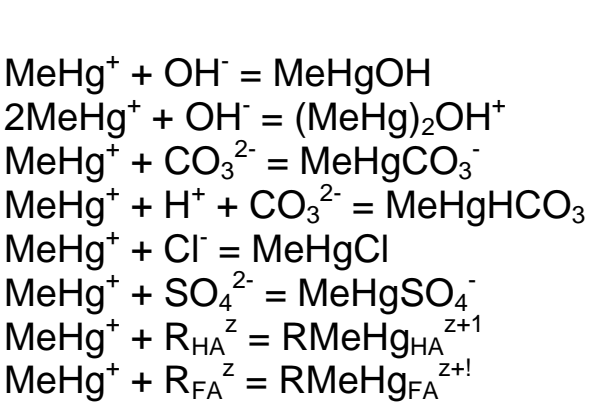 & $\begin{array}{l}\text { MeHg } \\
\quad 9.47 \\
11.85 \\
6.1 \\
12.95 \\
5.45 \\
2.64 \\
0.3 \\
0.3\end{array}$ & $\begin{array}{l}\text { De Robertis et al. (1998) } \\
\text { De Robertis et al. (1998) } \\
\text { Rabenstein et al. (1976) } \\
\text { Loux (2007) } \\
\text { De Robertis et al. (1998) } \\
\text { De Robertis et al. (1998) } \\
\text { Tipping (2007) } \\
\text { Tipping (2007) }\end{array}$ \\
\hline $\begin{array}{l}\mathrm{Ag}^{+}+\mathrm{OH}^{-}=\mathrm{AgOH} \\
\mathrm{Ag}^{+}+2 \mathrm{OH}^{-}=\mathrm{Ag}(\mathrm{OH})_{2}^{-} \\
\mathrm{Ag}^{+}+\mathrm{SO}_{4}^{2-}=\mathrm{AgSO}_{4}^{-} \\
\mathrm{Ag}^{+}+\mathrm{Cl}^{-}=\mathrm{AgCl}^{-} \\
\mathrm{Ag}^{+}+2 \mathrm{Cl}^{-}=\mathrm{AgCl}_{2}^{-}\end{array}$ & $\begin{array}{l}\mathbf{A g} \\
2.0 \\
3.99 \\
1.3 \\
3.31 \\
5.25\end{array}$ & $\begin{array}{l}\text { Smith and Martell (1976) } \\
\text { Smith and Martell (1976) } \\
\text { Smith and Martell (1976) } \\
\text { Smith and Martell (1976) } \\
\text { Smith and Martell (1976) }\end{array}$ \\
\hline $\begin{array}{l}\mathrm{In}^{3+}+\mathrm{Cl}^{-}=\mathrm{InCl}^{2+} \\
\mathrm{In}^{3+}+2 \mathrm{Cl}^{-}=\operatorname{InCl} 2^{+} \\
\mathrm{In}^{3+}+3 \mathrm{Cl}^{-}=\operatorname{lnCl} \mathrm{In}_{3} \\
\mathrm{In}^{3+}+\mathrm{NO}_{3}{ }^{-}=\operatorname{InNO}{ }_{3}^{2+} \\
\mathrm{In}^{3+}+2 \mathrm{NO}_{3}^{-}=\ln \left(\mathrm{NO}_{3}\right)_{2}{ }^{+} \\
\mathrm{In}^{3+}+\mathrm{SO}_{4}{ }^{2-}=\ln \mathrm{SO}_{4}^{+} \\
\mathrm{In}^{3+}+2 \mathrm{SO}_{4}{ }^{2-}=\ln \left(\mathrm{SO}_{4}\right)_{2}{ }^{-} \\
\mathrm{In}^{3+}+3 \mathrm{SO}_{4}{ }^{2-}=\ln \left(\mathrm{SO}_{4}\right)_{3}{ }^{3-} \\
\text { Table } 1 \text { (Continue) }\end{array}$ & $\begin{array}{l}\text { In } \\
2.4 \\
3.44 \\
4.3 \\
0.18 \\
-0.31 \\
1.74 \\
2.6 \\
3\end{array}$ & $\begin{array}{l}\text { IUPAC }(2001) \\
\text { IUPAC (2001) } \\
\text { IUPAC (2001) } \\
\text { IUPAC (2001) } \\
\text { IUPAC (2001) } \\
\text { IUPAC (2001) } \\
\text { IUPAC (2001) } \\
\text { IUPAC (2001) }\end{array}$ \\
\hline $\begin{array}{l}\mathrm{In}^{3+}+\mathrm{OH}^{-}=\mathrm{InOH}^{2+} \\
\mathrm{In}^{3+}+2 \mathrm{OH}^{-}=\ln (\mathrm{OH})_{2}^{+}\end{array}$ & $\begin{array}{l}9.47 \\
20.2\end{array}$ & $\begin{array}{l}\text { Martell and Smith (2001) } \\
\text { Martell and Smith (2001) }\end{array}$ \\
\hline
\end{tabular}




$$
\begin{aligned}
& \mathrm{In}^{3+}+3 \mathrm{OH}^{-}=\ln (\mathrm{OH})_{3} \\
& \mathrm{In}^{3+}+4 \mathrm{OH}^{-}=\operatorname{In}(\mathrm{OH})_{4}{ }^{-} \\
& 2 \mathrm{In}^{3+}+2 \mathrm{OH}^{-}=\ln _{2}(\mathrm{OH})_{2}{ }^{4+} \\
& 4 \mathrm{In}^{3+}+4 \mathrm{OH}^{-}=\ln _{4}(\mathrm{OH})_{4}{ }^{8+} \\
& 4 \mathrm{In}^{3+}+6 \mathrm{OH}^{-}=\operatorname{In}_{4}(\mathrm{OH})_{6}{ }^{6+} \\
& \mathrm{In}^{3+}+\mathrm{R}_{\mathrm{HA}^{\mathrm{z}}}=\mathrm{RIn}_{\mathrm{HA}}^{\mathrm{Z}+3} \\
& \mathrm{In}^{3+}+\mathrm{R}_{\mathrm{FA}}^{\mathrm{z}}=\mathrm{RIn}_{\mathrm{FA}}^{\mathrm{Z}+3}
\end{aligned}
$$

$$
\begin{aligned}
& \mathrm{AsO}_{4}{ }^{3-}+\mathrm{H}^{+}=\mathrm{HAsO}_{4}{ }^{2-} \\
& \mathrm{AsO}_{4}{ }^{3-}+2 \mathrm{H}^{+}=\mathrm{H}_{2} \mathrm{AsO}_{4}{ }^{-} \\
& \mathrm{AsO}_{4}{ }^{3-}+3 \mathrm{H}^{+}=\mathrm{H}_{3} \mathrm{AsO}_{4} \\
& \mathrm{AsO}_{4}{ }^{3-}+2 \mathrm{H}^{+}+\mathrm{Fe}^{2+}=\mathrm{FeH}_{2} \mathrm{AsO}_{4}{ }^{+} \\
& \mathrm{AsO}_{4}{ }^{3-}+\mathrm{H}^{+}+\mathrm{Fe}^{2+}=\mathrm{FeHAsO}_{4} \\
& \mathrm{AsO}_{4}{ }^{3-}+\mathrm{Fe}^{2+}=\mathrm{FeAsO}_{4} \\
& \mathrm{AsO}_{4}{ }^{3-}+\mathrm{H}^{+}+\mathrm{Mn}^{2+}=\mathrm{MnHAsO}_{4} \\
& \mathrm{AsO}_{4}{ }^{3-}+\mathrm{Mn}^{2+}=\mathrm{MnAsO}_{4}{ }^{-} \\
& \mathrm{AsO}_{4}{ }^{3-}+\mathrm{H}^{+}+\mathrm{Mg}^{2+}=\mathrm{MgHAsO}_{4} \\
& \mathrm{AsO}_{4}{ }^{3-}+\mathrm{Mg}^{2+}=\mathrm{MgAsO}_{4}^{-} \\
& \mathrm{AsO}_{4}{ }^{3-}+2 \mathrm{H}^{+}+\mathrm{Ca}^{2+}=\mathrm{CaH}_{2} \mathrm{AsO}_{4}{ }^{+} \\
& \mathrm{AsO}_{4}{ }^{3-}+\mathrm{H}^{+}+\mathrm{Ca}^{2+}=\mathrm{CaHASO}_{4} \\
& \mathrm{AsO}_{4}{ }^{3-}+\mathrm{Ca}^{2+}=\mathrm{CaAsO}_{4} \\
& \mathrm{MoO}_{4}{ }^{2-}+\mathrm{H}^{+}=\mathrm{HMoO}_{4}^{-} \\
& \mathrm{MoO}_{4}{ }^{2-}+2 \mathrm{H}^{+}=\mathrm{H}_{2} \mathrm{MoO}_{4} \\
& 7 \mathrm{MoO}_{4}{ }^{2-}+8 \mathrm{H}^{+}=\mathrm{Mo}_{7} \mathrm{O}_{24}{ }^{6-}+4 \mathrm{H}_{2} \mathrm{O} \\
& 7 \mathrm{MoO}_{4}{ }^{2-}+9 \mathrm{H}^{+}=\mathrm{HMO}_{7} \mathrm{O}_{24}{ }^{5-}+4 \mathrm{H}_{2} \mathrm{O} \\
& 7 \mathrm{MoO}_{4}{ }^{2-}+10 \mathrm{H}^{+}=\mathrm{H}_{2} \mathrm{Mo}_{7} \mathrm{O}_{24}{ }^{4-}+4 \mathrm{H}_{2} \mathrm{O} \\
& 7 \mathrm{MoO}_{4}{ }^{2-}+11 \mathrm{H}^{+}=\mathrm{H}_{3} \mathrm{Mo}_{7} \mathrm{O}_{24}{ }^{3-}+4 \mathrm{H}_{2} \mathrm{O} \\
& 8 \mathrm{MoO}_{4}{ }^{2-}+12 \mathrm{H}^{+}=\mathrm{Mo}_{8} \mathrm{O}_{26}{ }^{4-}+6 \mathrm{H}_{2} \mathrm{O} \\
& 8 \mathrm{MoO}_{4}{ }^{2-}+13 \mathrm{H}^{+}=\mathrm{HMO}_{8} \mathrm{O}_{26}{ }^{3-}+6 \mathrm{H}_{2} \mathrm{O} \\
& 8 \mathrm{MoO}_{4}{ }^{2-}+15 \mathrm{H}^{+}=\mathrm{H}_{3} \mathrm{Mo}_{8} \mathrm{O}_{26}{ }^{-}+6 \mathrm{H}_{2} \mathrm{O} \\
& \mathrm{MoO}_{4}{ }^{2-}+\mathrm{Ca}^{2+}=\mathrm{CaMoO}_{4} \\
& \mathrm{MoO}_{4}{ }^{2-}+\mathrm{Mg}^{2+}=\mathrm{MgMoO}_{4} \\
& \mathrm{MoO}_{4}^{2-}+\mathrm{K}^{+}=\mathrm{KMoO}_{4}^{-} \\
& \mathrm{MoO}_{4}{ }^{2-}+\mathrm{Na}^{+}=\mathrm{NaMoO}_{4}{ }^{-}
\end{aligned}
$$$$
\mathrm{Sb}(\mathrm{OH})_{6}{ }^{-}+\mathrm{H}^{+}=\mathrm{Sb}(\mathrm{OH})_{5}+\mathrm{H}_{2} \mathrm{O}
$$$$
\mathrm{Sb}(\mathrm{OH})_{6}{ }^{-}+2 \mathrm{H}^{+}=\mathrm{Sb}(\mathrm{OH})_{4}{ }^{+}+2 \mathrm{H}_{2} \mathrm{O}
$$

\section{As}

11.80

18.79

21.09

5.15

6.1

$-13.60$

15.54

6.1

14.7

6.3

20.09

14.46

4.36

Martell and Smith (2001)

Martell and Smith (2001)

Martell and Smith (2001)

Martell and Smith (2001)

Martell and Smith (2001)

Estimated

Estimated

Nordstrom and Archer (2003)

Nordstrom and Archer (2003)

Nordstrom and Archer (2003)

Whiting (1992)

Whiting (1992)

Whiting (1992)

Whiting (1992)

Whiting (1992)

Whiting (1992)

Whiting (1992)

Bothe and Brown (1999)

Bothe and Brown (1999)

Bothe and Brown (1999)

Mo

4.299

8.164

52.99

59.377

64.169

67.405

71.62

73.38

76.34

2.57

2.958

1.29

1.66

Schecher and McAvoy (1998)

Schecher and McAvoy (1998)

Schecher and McAvoy (1998)

Schecher and McAvoy (1998)

Schecher and McAvoy (1998)

Schecher and McAvoy (1998)

Yagasaki et al. (1987)

Yagasaki et al. (1987)

Yagasaki et al. (1987)

Essington (1992)

Essington (1992)

Essington (1992)

Essington (1992)

$\mathrm{Sb}$

$2.82 \quad$ Filella and May (2003)

$0.54 \quad$ Filella and May (2003) 
Table 2. Mean concentrations ( $\pm S D$ ) of total dissolved solutes including fulvic and humic acids in water overlying Lake Tantaré sediments, as well as free-ion activity, major trace element species and saturation index $\left(S I=\log I A P / K_{s}\right)$ predicted by WHAM 6 (see section 3.1 for details on the thermodynamic calculations).

\begin{tabular}{|c|c|c|c|c|}
\hline Solute & Total concentration $^{\mathrm{a}}$ & Free-ion activity $^{\mathrm{d}}$ & Major species $^{\mathrm{e}}(\%)$ & $\mathrm{SI}^{\mathrm{f}}$ \\
\hline $\mathrm{Ag}$ & $6.3 \pm 3.6 \times 10^{-12} \mathrm{M}$ & $\left(\mathrm{Ag}^{+}\right)=5.94 \times 10^{-12}$ & $\mathrm{Ag}^{+}(94 \%)$ & $\leq-11.9$ \\
\hline As & $1.9 \pm 1.0 \times 10^{-9} \mathrm{M}$ & $\left(\mathrm{AsO}_{4}{ }^{3-}\right)=1.25 \times 10^{-16}$ & $\mathrm{H}_{2} \mathrm{AsO}_{4}^{-}(96 \%)$ & $=-64.3$ \\
\hline $\mathrm{Ca}$ & $2.0 \pm 0.2 \times 10^{-5} \mathrm{M}$ & $\left(\mathrm{Ca}^{2+}\right)=1.65 \times 10^{-5}$ & $\mathrm{Ca}^{2+}(83 \%)$ & $\leq-5.3$ \\
\hline $\mathrm{Cd}$ & $2.8 \pm 0.4 \times 10^{-10} \mathrm{M}$ & $\left(\mathrm{Cd}^{2+}\right)=1.83 \times 10^{-10}$ & $\mathrm{Cd}^{2+}(65 \%)$ & $\leq-4.9$ \\
\hline $\mathrm{Cu}$ & $2.7 \pm 1.3 \times 10^{-9} \mathrm{M}$ & $\left(\mathrm{Cu}^{2+}\right)=1.7 \times 10^{-11}$ & Cu-HS (99.3\%) & $\leq-7.2$ \\
\hline $\mathrm{Hg}$ & $3.7 \pm 1.0 \times 10^{-12} \mathrm{M}$ & $\left(\mathrm{Hg}^{2+}\right)=1.45 \times 10^{-34}$ & $\mathrm{Hg}-\mathrm{HS}(99.9 \%)$ & $=-24.3$ \\
\hline $\ln$ & $5.0 \pm 2.0 \times 10^{-13} \mathrm{M}$ & $\left(\ln ^{3+}\right)=3.98 \times 10^{-18}$ & In-HS (78\%) & $\leq-5.7$ \\
\hline $\mathrm{MeHg}$ & $2.6 \pm 1.0 \times 10^{-13} \mathrm{M}$ & $\left(\mathrm{MeHg}^{+}\right)=1.68 \times 10^{-14}$ & $\mathrm{MeHgOH}(79 \%)$ & \\
\hline $\mathrm{Mg}$ & $8.7 \pm 0.3 \times 10^{-6} \mathrm{M}$ & $\left(\mathrm{Mg}^{2+}\right)=7.75 \times 10^{-6}$ & $\mathrm{Mg}^{2+}(84 \%)$ & $\leq-6.6$ \\
\hline Mo & $3.1 \pm 0.8 \times 10^{-10} \mathrm{M}$ & $\left(\mathrm{MoO}_{4}^{2-}\right)=2.91 \times 10^{-10}$ & $\mathrm{MoO}_{4}^{2-}(94 \%)$ & $\leq-8.7$ \\
\hline $\mathrm{Pb}$ & $0.4 \pm 0.2 \times 10^{-9} \mathrm{M}$ & $\left(\mathrm{Pb}^{2+}\right)=8.49 \times 10^{-11}$ & $\mathrm{~Pb}-\mathrm{HS}(77 \%)$ & $\leq-5.9$ \\
\hline $\mathrm{Sb}$ & $1.5 \pm 0.1 \times 10^{-10} \mathrm{M}$ & $\left(\mathrm{Sb}(\mathrm{OH})_{6}^{-}\right)=1.5 \times 10^{-10}$ & $\mathrm{Sb}(\mathrm{OH})_{6}^{-}(100 \%)$ & \\
\hline $\mathrm{Zn}$ & $6.0 \pm 1.0 \times 10^{-8} \mathrm{M}$ & $\left(\mathrm{Zn}^{2+}\right)=4.19 \times 10^{-8}$ & $\mathrm{Zn}^{2+}(70 \%)$ & $\leq-6.3$ \\
\hline $\mathrm{C}_{\text {org }}$ & $2.5 \pm 0.4 \times 10^{-3} \mathrm{~g} \mathrm{~L}^{-1}$ & & & \\
\hline$H A^{b}$ & $5.1 \pm 0.8 \times 10^{-4} \mathrm{~g} \mathrm{~L}^{-1}$ & & & \\
\hline$F A^{b}$ & $4.6 \pm 0.8 \times 10^{-3} \mathrm{~g} \mathrm{~L}^{-1}$ & & & \\
\hline$[\mathrm{L}]_{\mathrm{T}}{ }^{\mathrm{c}}$ & $3.5 \times 10^{-5} \mathrm{~mol}$ sites $\mathrm{L}^{-1}$ & & & \\
\hline
\end{tabular}

a: Average of between 19 and 80 measurements; [Ag], [As], [Cd], [In], [Mo], [Pb] and [Sb] were fron previous studies at the same site (see text).

b. To estimate $[\mathrm{FA}]$ and $[\mathrm{HA}]$ it was assumed that all $\mathrm{C}_{\text {org }}$ is humic substances comprising $50 \% \mathrm{C}$ with a molar ratio $[\mathrm{FA}]:[\mathrm{HA}]$ of 9.

c: $[L]_{\mathrm{T}}=[\mathrm{HA}] \times \mathrm{n}_{\mathrm{HA}}+[\mathrm{FA}] \times \mathrm{n}_{\mathrm{FA}}$ where $\mathrm{n}_{\mathrm{HA}}$ is $4.9 \times 10^{-3}$ mol site per $\mathrm{g}$ of $\mathrm{HA}$ and $\mathrm{n}_{\mathrm{FA}}$ is $7.1 \times 10^{-3}$ mo site per $g$ of $F A$

d: $(X)$ is for the activity of species $X$.

e: HS is for humic substances.

f: (hydr)oxide and carbonate solid phases were considered. 
Table 3. Mean ( $\pm \mathrm{SD})$ trace element/Fe (TE/Fe), trace element/organic $C\left(T E / \mathrm{C}_{\text {org }}\right)$ and $\mathrm{C}_{\text {org }} / \mathrm{N}$ molar ratios in the diagenetic material collected on Teflon sheets in Lake Tantaré sediment.

\begin{tabular}{llll}
\hline $\mathrm{TE} / \mathrm{Fe}$ & Mean $( \pm \mathrm{SD})$ & $\mathrm{TE} / \mathrm{C}_{\text {org }}$ & Mean $( \pm \mathrm{SD})$ \\
\hline $\mathrm{Ag} / \mathrm{Fe}$ & $2.8 \pm 1.0 \times 10^{-7}$ & $\mathrm{Ag} / \mathrm{C}_{\text {org }}$ & $1.1 \pm 0.5 \times 10^{-7}$ \\
$\mathrm{As} / \mathrm{Fe}$ & $2.8 \pm 0.2 \times 10^{-4}$ & $\mathrm{As} / \mathrm{C}_{\text {org }}$ & $1.1 \pm 0.2 \times 10^{-4}$ \\
$\mathrm{Ca} / \mathrm{Fe}$ & $5.6 \pm 1.1 \times 10^{-3}$ & $\mathrm{Ca} / \mathrm{C}_{\text {org }}$ & $2.2 \pm 0.5 \times 10^{-3}$ \\
$\mathrm{Cd} / \mathrm{Fe}$ & $9.8 \pm 1.0 \times 10^{-7}$ & $\mathrm{Cd} / \mathrm{C}_{\text {org }}$ & $3.9 \pm 0.5 \times 10^{-7}$ \\
$\mathrm{Cu} / \mathrm{Fe}$ & $2.8 \pm 0.7 \times 10^{-5}$ & $\mathrm{Cu} / \mathrm{C}_{\text {org }}$ & $1.1 \pm 0.2 \times 10^{-5}$ \\
$\mathrm{Hg} / \mathrm{Fe}$ & $1.3 \pm 0.3 \times 10^{-7}$ & $\mathrm{Hg} / \mathrm{C}_{\text {org }}$ & $4.9 \pm 0.7 \times 10^{-8}$ \\
$\mathrm{In} / \mathrm{Fe}$ & $1.4 \pm 0.4 \times 10^{-7}$ & $\mathrm{In} / \mathrm{C}_{\text {org }}$ & $5.4 \pm 2.0 \times 10^{-8}$ \\
$\mathrm{MeHg} / \mathrm{Fe}$ & $6.5 \pm 1.9 \times 10^{-10}$ & $\mathrm{MeHg} / \mathrm{C}_{\text {org }}$ & $2.5 \pm 0.6 \times 10^{-10}$ \\
$\mathrm{Mg} / \mathrm{Fe}$ & $1.2 \pm 0.2 \times 10^{-3}$ & $\mathrm{Mg} / \mathrm{C}_{\text {org }}$ & $4.6 \pm 0.8 \times 10^{-4}$ \\
$\mathrm{Mo} / \mathrm{Fe}$ & $6.3 \pm 0.3 \times 10^{-5}$ & $\mathrm{Mo} / \mathrm{C}_{\text {org }}$ & $2.5 \pm 0.3 \times 10^{-5}$ \\
$\mathrm{~Pb} / \mathrm{Fe}$ & $1.9 \pm 0.2 \times 10^{-4}$ & $\mathrm{~Pb} / \mathrm{C}_{\text {org }}$ & $7.4 \pm 1.0 \times 10^{-5}$ \\
$\mathrm{Sb} / \mathrm{Fe}$ & $3.1 \pm 0.6 \times 10^{-6}$ & $\mathrm{Sb} / \mathrm{C}_{\text {org }}$ & $1.2 \pm 0.3 \times 10^{-6}$ \\
$\mathrm{Zn} / \mathrm{Fe}$ & $9.0 \pm 2.9 \times 10^{-5}$ & $\mathrm{Zn} / \mathrm{C}_{\text {org }}$ & $3.6 \pm 1.4 \times 10^{-5}$ \\
$\mathrm{C}_{\text {org }} / \mathrm{N}$ & $15.3 \pm 3.4$ & \\
$\mathrm{C}_{\text {org }} / \mathrm{Fe}$ & $2.6 \pm 0.3$ & \\
$\mathrm{HS} / \mathrm{Fe}{ }^{a}$ & 0.41 &
\end{tabular}


Table 5. Total measured concentrations of the elements in the top 0.5-cm layer of Lake Tantaré sediments compared to those predicted to be associated with diagenetic material or to organic matter in this sediment layer. Also given are the Fe oxyhydroxide (Fe-ox) and organic $\mathrm{C}$ concentrations and the $\mathrm{C}_{\text {org }} / \mathrm{N}$ molar ratio in this sediment layer.

\begin{tabular}{|c|c|c|c|}
\hline & \multirow{2}{*}{$\begin{array}{l}\text { Measured } \\
\text { concentration } \\
\text { molar ratio }\end{array}$} & \multicolumn{2}{|c|}{ Predicted concentration } \\
\hline & & Authigenic $^{a}$ & Organically-bound $^{\mathrm{b}}$ \\
\hline$\left\{\mathrm{C}_{\mathrm{org}}\right\}\left(\mathrm{mol} \mathrm{C} \mathrm{g}{ }^{-1}\right)$ & $2.02 \pm 0.08 \times 10^{-2}$ & & \\
\hline$\{F e-O x\}\left(\mathrm{mol} \mathrm{g}^{-1}\right)$ & $1.55 \pm 0.05 \times 10^{-3}$ & & \\
\hline $\mathrm{C}_{\text {org }} / \mathrm{N}$ & 15.5 & & \\
\hline$\left\{\mathrm{C}_{\text {org }}\right\} /\{\mathrm{Fe}-\mathrm{ox}\}$ & 13 & & \\
\hline$\{\mathrm{Hg}\}_{\mathrm{I}}\left(\mathrm{mol} \mathrm{g}^{-1}\right)$ & $3.0 \pm 0.1 \times 10^{-9}$ & $1.9 \pm 0.5 \times 10^{-10}$ & $1.0 \pm 0.2 \times 10^{-9}$ \\
\hline$\{\mathrm{MeHg}\}\left(\mathrm{mol} \mathrm{g}^{-1}\right)$ & $7.6 \pm 1.1 \times 10^{-11}$ & $1.0 \pm 0.3 \times 10^{-12}$ & $5.0 \pm 1.2 \times 10^{-12}$ \\
\hline$\{\mathrm{Ag}\}\left(\mathrm{mol} \mathrm{g}^{-1}\right)$ & $2.8 \times 10^{-9}$ & $4.3 \pm 1.4 \times 10^{-10}$ & \\
\hline$\{$ As $\}\left(\mathrm{mol} \mathrm{g}^{-1}\right)$ & $2.3 \pm 0.1 \times 10^{-7}$ & $4.3 \pm 0.3 \times 10^{-7}$ & \\
\hline$\{\mathrm{Cd}\}\left(\mathrm{mol} \mathrm{g}^{-1}\right)$ & $1.8 \times 10^{-9}$ & $1.5 \pm 0.2 \times 10^{-9}$ & $7.8 \pm 1.1 \times 10^{-9}$ \\
\hline$\{\mathrm{Cu}\}\left(\mathrm{mol} \mathrm{g}^{-1}\right)$ & $3.7 \times 10^{-7}$ & $4.4 \pm 1.1 \times 10^{-8}$ & $2.2 \pm 0.4 \times 10^{-7}$ \\
\hline$\{\ln \}\left(\mathrm{mol} \mathrm{g}^{-1}\right)$ & $1.1 \times 10^{-9}$ & $2.1 \pm 0.6 \times 10^{-10}$ & $1.1 \pm 0.4 \times 10^{-9}$ \\
\hline$\{\mathrm{Mo}\}\left(\mathrm{mol} \mathrm{g}^{-1}\right)$ & $1.2 \pm 0.01 \times 10^{-7}$ & $1.0 \pm 0.1 \times 10^{-7}$ & \\
\hline$\{\mathrm{Pb}\}\left(\mathrm{mol} \mathrm{g}^{-1}\right)$ & $5.4 \pm 0.2 \times 10^{-7}$ & $2.9 \pm 0.3 \times 10^{-7}$ & $1.5 \pm 0.2 \times 10^{-6}$ \\
\hline$\{\mathrm{Sb}\}\left(\mathrm{mol} \mathrm{g}^{-1}\right)$ & $1.6 \times 10^{-8}$ & $4.7 \pm 0.9 \times 10^{-9}$ & \\
\hline$\{\mathrm{Zn}\}\left(\mathrm{mol} \mathrm{g}^{-1}\right)$ & $1.1 \times 10^{-6}$ & $1.4 \pm 0.5 \times 10^{-7}$ & $7.2 \pm 2.8 \times 10^{-7}$ \\
\hline \multicolumn{4}{|c|}{$\begin{array}{l}\text { a: obtained by multiplying the TE/Fe ratios given in Table } 2 \text { by the sedimentary } F \\
\text { oxyhydroxide concentration in the top } 0.5-\mathrm{cm} \text { sediment layer. } \\
\text { b: obtained by multiplying the } T E / C_{\text {org }} \text { ratios given in Table } 2 \text { by the sedimentary } C_{0} \\
\text { concentration in the top } 0.5-\mathrm{cm} \text { sediment layer. }\end{array}$} \\
\hline
\end{tabular}



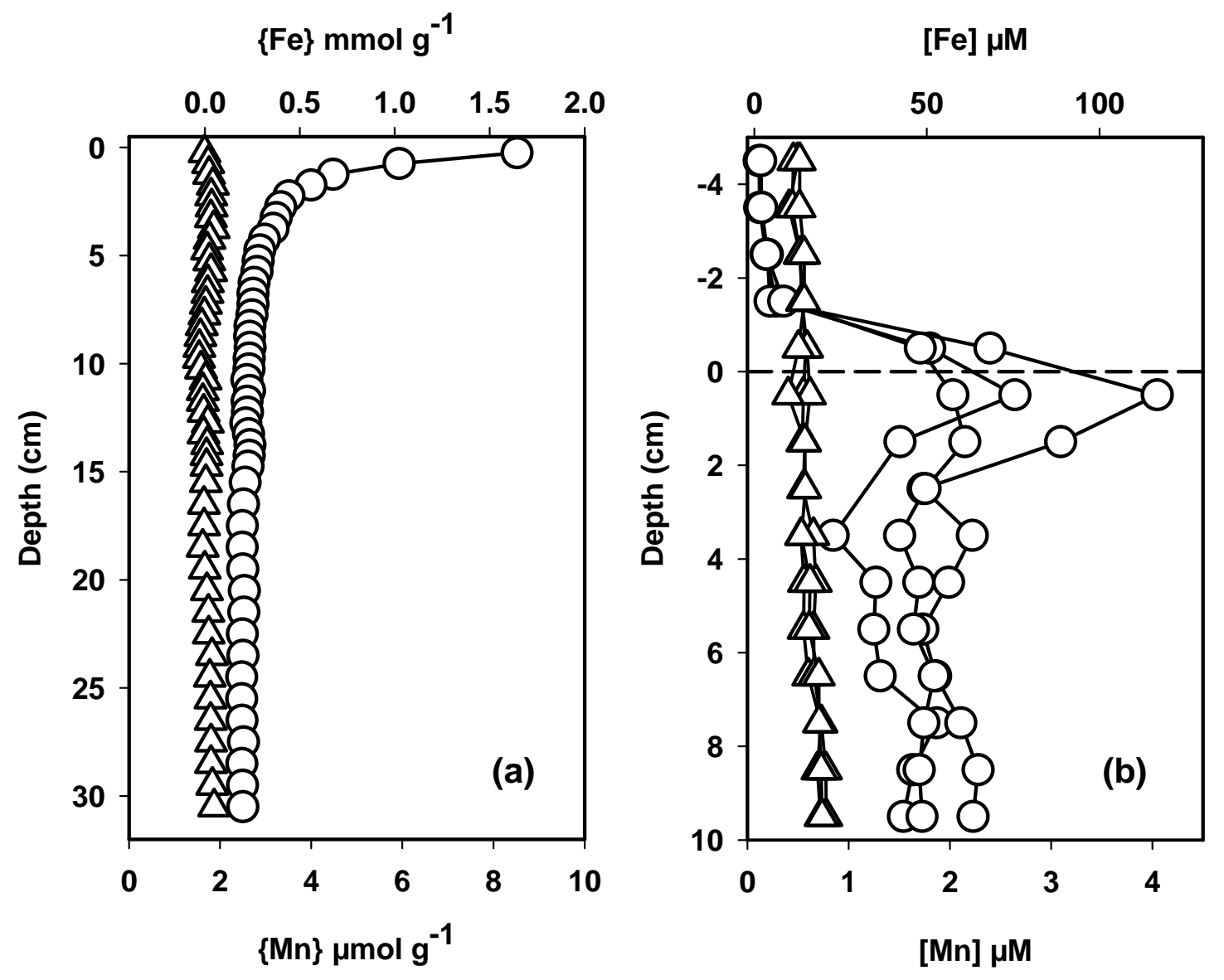

Fig. 1

Figure 1. Depth distributions of Fe (o) and $\mathrm{Mn}(\Delta)$ in sediments (a) and sediment porewaters (b) at the sampling site. 


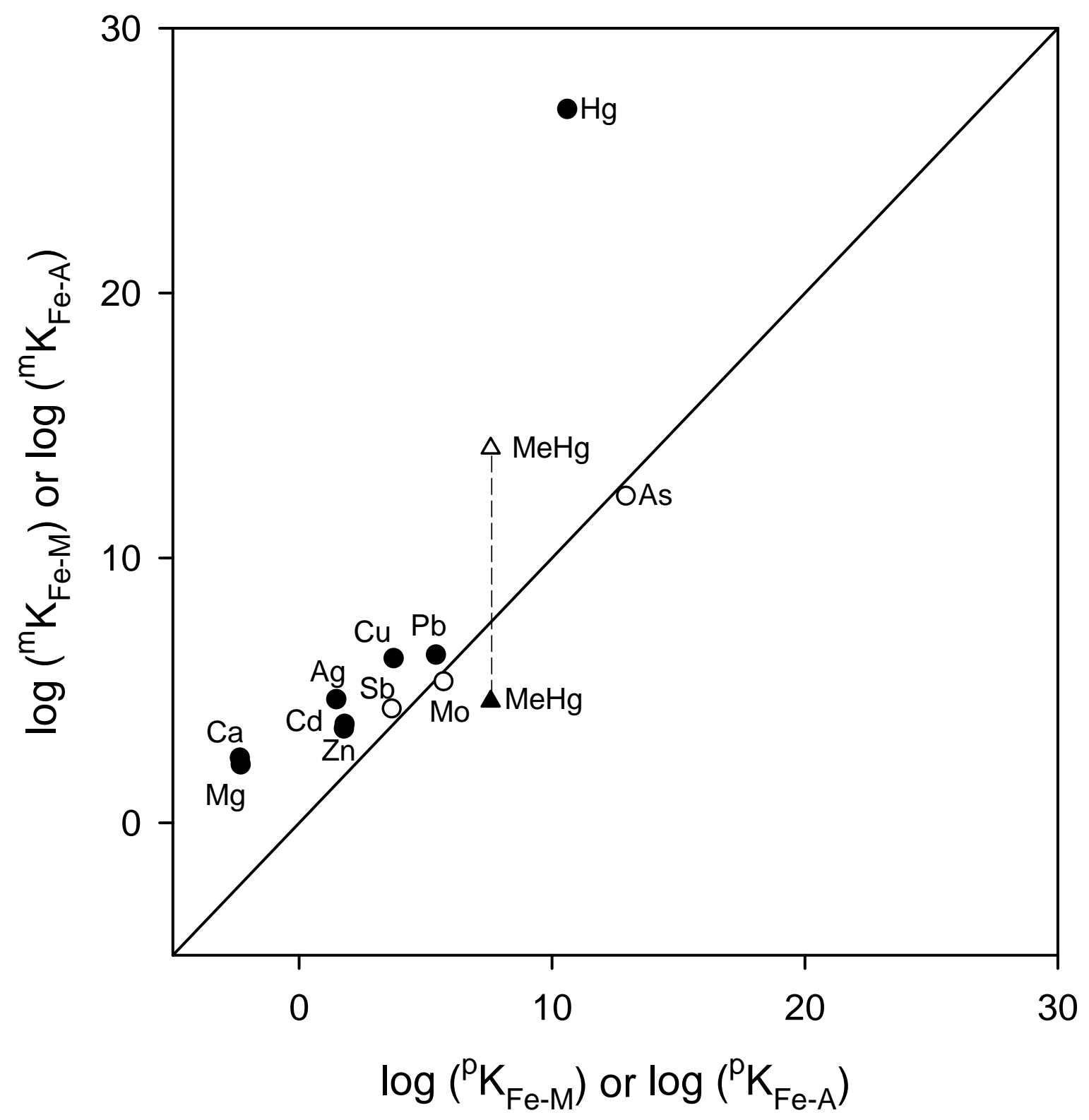

Fig. 2

Figure 2. Comparison between values of the conditional equilibrium constant obtained from in situ measurements $\left({ }^{m} K_{\mathrm{Fe}-\mathrm{M}}\right.$ and ${ }^{m} \mathrm{~K}_{\mathrm{Fe}-\mathrm{A}}$ ) with those predicted by the two-layer version of the surface complexation model $\left({ }^{p} K_{\mathrm{Fe}-\mathrm{M}}\right.$ and $\left.{ }^{p} K_{\mathrm{Fe}-\mathrm{A}}\right)$. The 1:1 line is shown. Open and filled circles are used for anions and cations (except $\mathrm{MeHg}$ ), respectively. Triangles represent ${ }^{p} K_{\mathrm{Fe}-\mathrm{M}}$ values obtained when the $\mathrm{MeHg}^{+}$activity was calculated with WHAM 6 using either default (open triangle) or revised (filled triangle) formation constants for $\mathrm{MeHg}$ complexes with both HA and FA. 


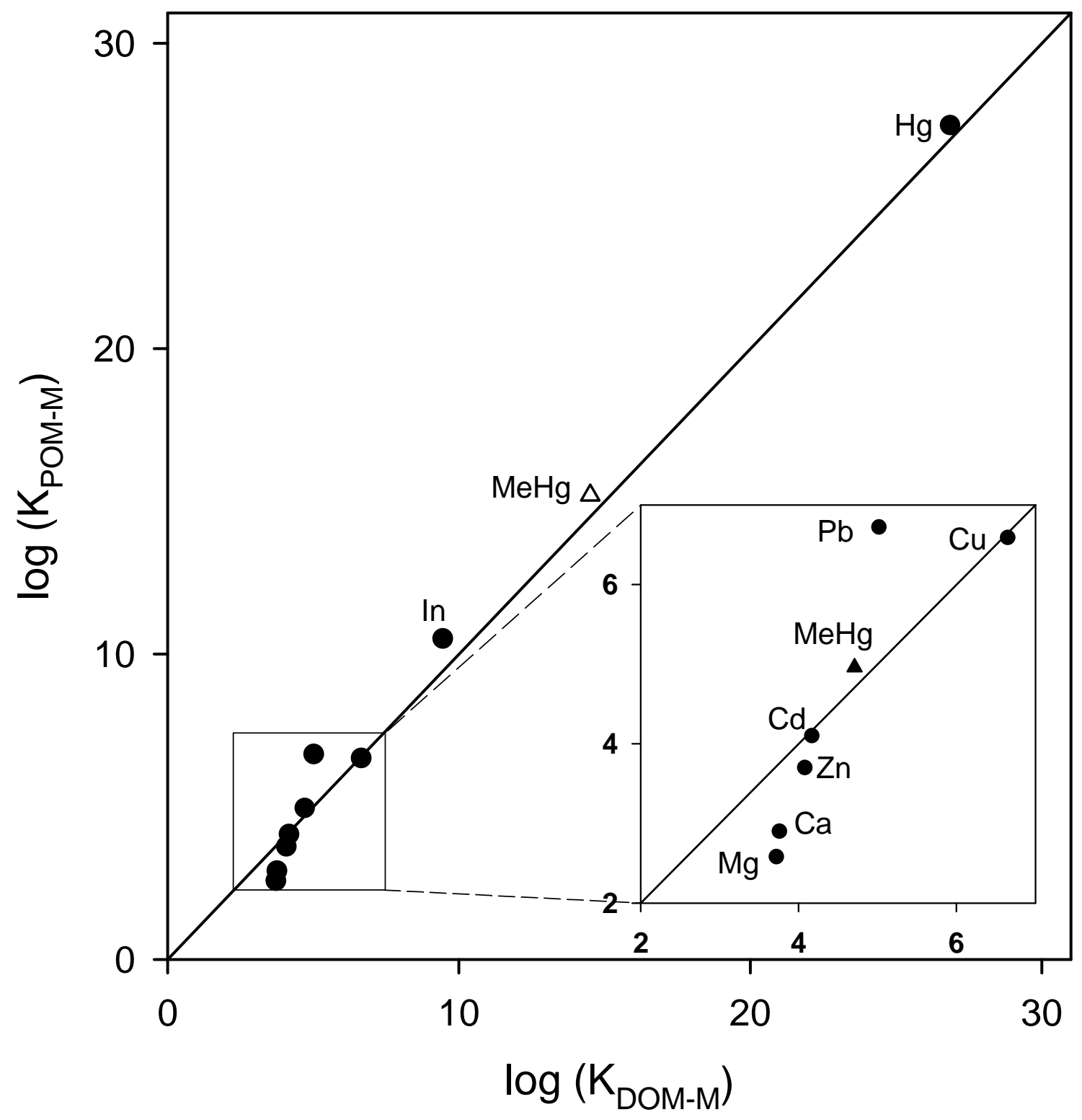

Fig. 3

Figure 3. Comparison between the conditional constants for trace metal binding with dissolved $\left(K_{D O M-M}\right)$ and adsorbed $\left(K_{P O M-M}\right)$ natural organic matter assumed to be humic substances. The 1:1 line is shown. Triangles represent values obtained when the $\mathrm{MeHg}^{+}$activity was calculated with WHAM 6 using either default (open triangle) or revised (filled triangle) formation constants for MeHg complexes with both HA and FA. 